\title{
THE BOTTOM OF THE LOOTED CAULDRON. PART I
}

\author{
JÁNOS GÁBOR TARBAY*-ZOLTÁN KIS**-BOGLÁRKA MARÓTI** \\ *Hungarian National Museum, Department of Archaeology \\ Múzeum krt. 14-16, H-1088 Budapest, Hungary \\ tarbayjgabor@gmail.com \\ **Nuclear Analysis and Radiography Department, Centre for Energy Research, Hungarian Academy of Sciences \\ 29-33 Konkoly Thege Miklós Str., H-1121 Budapest, Hungary \\ kis.zoltan@energia.mta.hu, maroti.boglarka@energia.mta.hu
}

\begin{abstract}
The following study deals with a looted metal sheet artefact probably originating from the Balkan region. Our main goal is to give a preliminary technological characterization of the object by the aid of four different analytical methods (macroand microscopic observations, Neutron and X-ray Radiography, X-ray Fluorescence Spectroscopy). Using these different techniques together allowed us to characterize this complex metal sheet object more precisely than it would have been possible by traditional archaeological methods. According to our results, it seems that the technological characters of the artefact (e.g. the manufacturing technology, decorations, repair marks) are very similar to the metal sheet cauldrons of the Late Bronze Age and Early Iron Age.

Keywords: Late Bronze Age-Early Iron Age, illicit antiquities trade, bronze metal sheet technology, round shield or cauldron, macro- and microscopic observations, Neutron and X-ray Radiography, Portable handheld X-ray Fluorescence Spectroscopy (pXRF)
\end{abstract}

\section{INTRODUCTION}

It is a well-known fact that in recent decades due to systematic looting and illicit antiquities trade, numerous finds of great value have been smuggled out from East- and Southeastern Europe. These artefacts have finally ended up in Western European auction houses (Hermann Historica, Gorny\&Mosch etc.) or they were sold to private collectors on online marketplaces such as eBay. Hungary, as the border of the Schengen Area lies at the crossroads of international smuggling routes therefore it is a key area of illicit antiquities trade toward the western part of the European Union. The artefact, which our study is dealing with, is one of the latest "victim" of this unfortunate phenomenon.

To compare with other cases, this remarkable object was confiscated at the Hungarian part of the Schengen border just before it had the chance to reach an auction house. The round-shaped bronze artefact was seized in 2008 by The National Tax and Customs Administration (NTCA) Bács-Kiskun County Tax and Customs Directorate at the border crossing of Hercegszántó from Mladenovic Toplica, a Serbian citizen who tried to smuggle the object to Germany and sell it to an auction house (Fig. 1). According to NTCA Bács-Kiskun County Tax and Customs Directorate, except from the smuggler's name and the year of confiscation, no additional data had been recorded about the artefact's exact find spot or circumstances of discovery. The only known fact about the object, beside the nationality of the smuggler, is the direction of his route which supports the possibility that the find spot could have been somewhere in the Balkans. The object remained unknown to research until 2014 when the Hungarian border control contacted Ildikó Szathmári and János Gábor Tarbay from the Archaeological Department of the Hungarian National Museum (HNM) for determining the authenticity of the artefact.

In the Archaeological Department of the HNM, preliminary macro- and microscopic observations were carried out on the artefacts by J. G. Tarbay. Based on the results of this analysis, the prehistoric origin of the object 


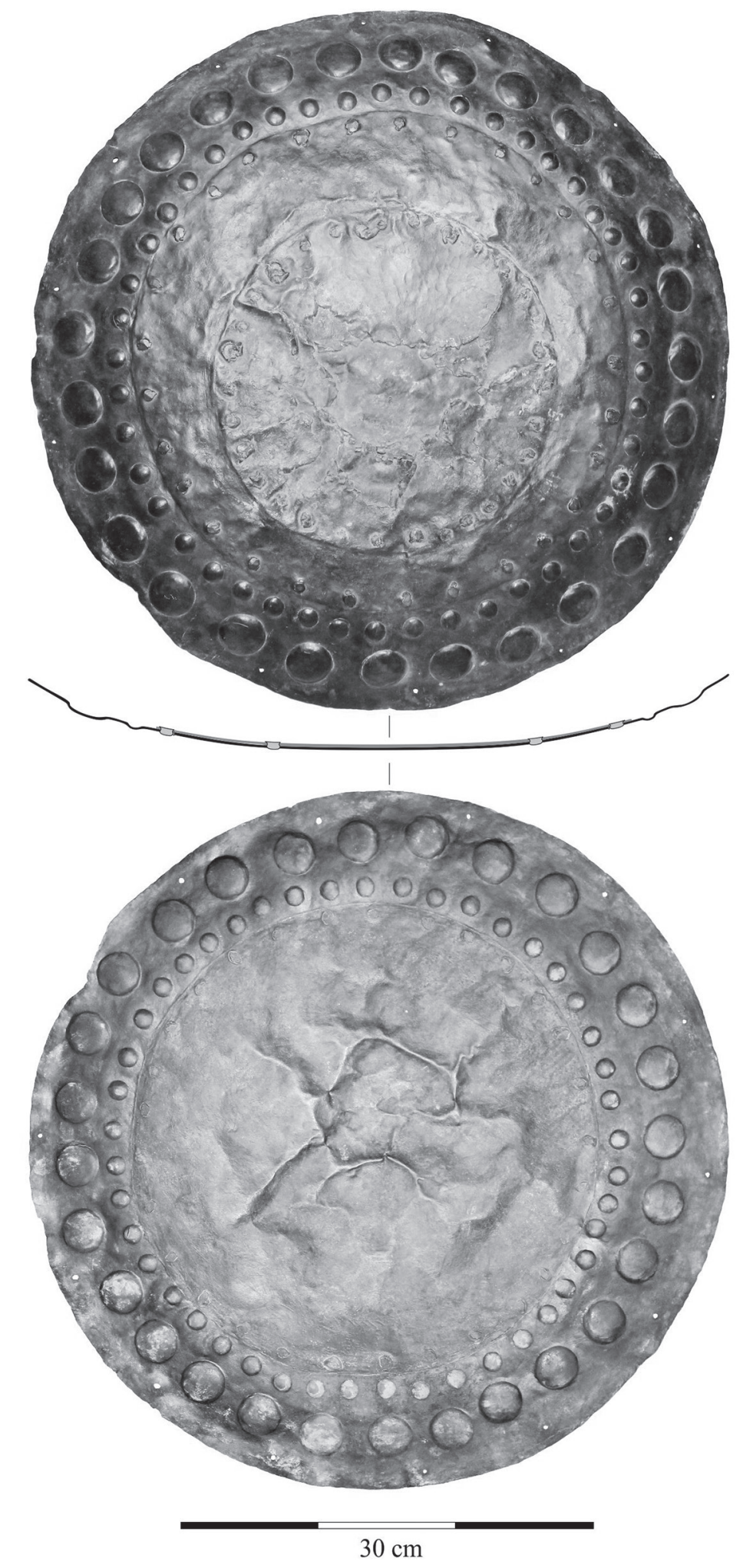

Fig. 1. Photography of the looted metal sheet artefact (Hungarian National Museum, Photos: J. G. Tarbay) 
seemed to be verified. However, the frequent appearance of professional forgeries ${ }^{1}$ called for further scientific investigation. In March 2015 Zoltán Kis and Boglárka Maróti, colleagues from the Nuclear Analysis and Radiography Department of the Centre for Energy Research, Hungarian Academy of Sciences (MTA EK NAL) were invited to perform neutron and X-ray radiography (NR, XR) and X-ray Fluorescence Spectroscopy (XRF) on the artefact. These analyses not just confirmed the authenticity of the artefact but also revealed significant information on its manufacturing technology. By the aid of the applied analyses it was possible to classify this unique object more precisely based on technological arguments and it could also tell more about its prehistoric use-life even if it is originating from a completely unknown context.

\section{METHODS}

\subsection{Macro- and microscopic observations}

The preliminary macro- and microscopic examination of the artefact was carried out by high resolution pictures and a dnt Digi-Micro Mobile microscope camera. Traceology, ${ }^{2}$ this long used visual analytical method, is suitable for documenting surface technological traits (usage, prehistoric manipulations, recent damages etc.), and for addressing questions regarding manufacturing techniques to limited extent. The results of the examination are very often hypothetical in nature, and need to be substantiated with additional analytical methods and experiments. In the Hungarian LBA (Late Bronze Age) research the method was first applied by Amália Mozsolics and then further taken by Géza Szabó in his archaeometallurgical and experimental archaeological studies. ${ }^{3}$

\subsection{Neutron and $X$-ray radiography}

Imaging is a powerful technique for non-destructive and non-invasive investigation of complex samples. ${ }^{4}$ Looking through and into objects made of a few varied materials, created by complex manufacturing processes and used for different purposes is a common objective. ${ }^{5}$ Based on the transmission images neutron and X-ray radiography (2D) and tomography (3D) could provide information about the inner structure of the sample by detecting the modification of an incident beam as it passes through matter. The complementary character of the two radiations can easily be understood. For neutrons, hydrogenous materials deliver high contrast, and many metals can easily be trans-illuminated. For X-rays, light elements (e.g. organic materials) have low contrast, and heavy elements (e.g. metals) are difficult to transilluminate.

The measurements were carried out at the RAD station of the Budapest Research Reactor (BRR). ${ }^{6}$ This station is capable carrying out bimodal imaging using both the thermal neutron beam of BRR and a portable X-ray source (ERESCO $42 \mathrm{MF3.1)}$ ). Using suitable scintillator screens neutrons and X-rays were converted into visible light, which was projected onto the chip of a digital camera (Andor Neo $5.5 \mathrm{sCMOS} 2560 \times 2160 \mathrm{px}$ ). The spatial resolution falls between $\mathrm{R}=200-400 \mu \mathrm{m}$ and the exposure times were in the second's range. Due to the large size of the object the imaging was carried out with several overlapping tiles by moving the sample into desired positions. The image processing and analysis were done with the latest version of the FIJI code. During imaging experiment, neutrons, unlike X-rays, could generate radioactive isotopes which reaction is called activation. A few days of decay after the imaging experiments can therefore be necessary to get rid of the induced radioactivity in the object. As the number of affected atoms is negligibly low, activation has no macroscopic effect on the physical integrity of the object, neither on its composition.

\footnotetext{
${ }^{1}$ See CRADDOCK 2009.

${ }^{2}$ See Semenov 1964; Thomas et al. 2011.

${ }^{3}$ See Mozsolics 1984; Szabó 2013.
}

\footnotetext{
${ }^{4}$ NEUTRONIMAGING\&ACTIVATIONGROUP 2011

${ }^{5}$ SZILÁGYI-KIS-SZENTMIKLÓSI 2016.

${ }^{6}$ Kis et al. 2015.
} 


\subsection{X-ray Fluorescence spectrometry}

$\mathrm{X}$-ray Fluorescence spectrometry (XRF) is a non-destructive analytical method for the elemental composition analysis of various types of objects, e.g. metals, glasses and ceramics. The technique is based on the detection of characteristic X-ray lines emitted after excitation of the atomic shell. The energies of the X-rays refer to the elements present in the sample (qualification), while the calculation of the elemental concentrations is based on their intensities (quantification). The sensitivity of the XRF method increases monotonously with the atomic number, making the technique well applicable in the analysis of copper based materials and alloys.

The measurements were carried out with an Olympus Innov-X Delta Premium type handheld XRF equipment, which is applicable for the analysis of elements heavier than Mg. ${ }^{7}$ The beam spot size of the XRF spectrometer is $3 \mathrm{~mm}$ in diameter, and the time requirement is $30 \mathrm{~s}$ per measurement point. The evaluation of the results is based on the Fundamental Parameters (FP) approach. This is a standardless method therefore it does not require calibration by the user. The detectable chemical elements in Alloy Plus mode are: $\mathrm{Ti}, \mathrm{V}, \mathrm{Cr}, \mathrm{Mn}, \mathrm{Fe}, \mathrm{Co}, \mathrm{Ni}, \mathrm{Cu}, \mathrm{Zn}$, W, Hf, Ta, Re, Pb, Bi, Zr, Nb, Mo, Ag, Sn, Sb, with some light elements as Mg, Al, Si, P.

The XRF technique can be used only as a near-surface analytical method, as the penetration depth of both the exciting radiation and the emitted X-ray photons are limited to few tens of microns depending on the composition of the sample. If the metal object is covered by patina or corrosion layer, the XRF results are not representative of the whole object's alloy composition. ${ }^{8}$

\section{ARCHAEOMETALLURGICAL CHARACTERIZATION OF THE ARTEFACT: RESULTS AND CONCLUSIONS}

\subsection{Preliminary description of the object-Macro- and microscopic observations}

The analysed artefact is a round-shaped, slightly convex metal sheet object with a relatively large size (Diameter: $50.5 \times 50.3 \mathrm{~cm}$, Height: $7.2 \mathrm{~cm}$, Thickness: $1 \mathrm{~mm}$, Weight: $1785 \mathrm{~g}$ ). Along the edges powerful hammering marks were clearly visible to the naked eye (Fig. 2.1, Fig. 3.1a). The shape of the edge is irregular and obvious damage like sections can be seen in two segments (Fig. 3.1.b). A few centimetres from the edge 13 small perforations can be observed in regular position, and on almost all of them imprint of rivets were visible (Fig. 3.2.c). The outer part of the round metal sheet is decorated with 28 larger and 46 smaller circle of embossed dots in irregular position. ${ }^{9}$ The imprints of embossing tools can only be seen on one side of the larger dots (Fig. 3.2.d), and on both sides of the smaller ones (Fig. 2.2, Fig. 3.2.e). In the middle of the artefact the contour of two metal sheet circle can be seen. In both cases oval-shaped hammer marks were observed along their edges (Fig. 2.5). Hammering marks were also visible on a few spot at the middle of the object. Based on the macroscopic examination, it seems that these metal sheets were joint together by rivets arranged in two rows (Fig. 2.4, 6, Fig. 3.2.f) ${ }^{10}$ In the outer rivet circle, close to the larger rivets, smaller ones were also observed in some cases (Fig. 2.4). The innermost part of the object was in a very fragmentary state. Due to its unknown context, it is not entirely clear whether it was the result of taphonomic process, usage, prehistoric manipulation or it can be interpreted as a recent damage caused by the finder. A "serrated" edge can be recognised on the surface of the damaged sheet. According to the results of the microscopic observation, it seems that this "serrated" phenomenon also continues on other parts of the object but its exact form is hard to determine by this method (Fig. 2.3). The reverse side of the artefact is completely smooth, as well as the lower parts of the outer rivet circle. Creasing of unknown origin can only be observed at the middle. A single round metal sheet can be seen here with traces of a less visible "fishbone-like" decoration arranged in one circle (Fig. 3.3). From the reverse side, imprint of embossing tools can also be detected in and around the dots (Fig. 3.2.d, e). During the macro- and microscopic examination of the artefact, remains of organic materials were not observed only traces of soil residues were identified in the innermost part of the object.

${ }^{7}$ Innov-X Systems, DELTA Premium Handheld XRF Analyzer Specifications, n.d. http://www.olympus-ims.com/hu/.downloads/ download/?file=285214185\&fl=en_US (accessed December 17, 2013). ${ }^{8}$ RobBiola-Blengino-Fiaud 1998.

\footnotetext{
${ }^{9}$ The average diameter of the larger ones is $3.2 \mathrm{~cm}$ and $1.5 \mathrm{~cm}$ of the smaller ones.

${ }^{10} 29$ large rivets can be found in the outer circle and 30 in the inner one.
} 
As a result of the macro- and microscopic examination, the picture of a peculiar metal sheet object with embossed decoration was revealed, which consists of different layers of metal sheet circles joint together by riveting. However, the limits of the applied preliminary method also become clear. It was not possible to determine significant technological questions such as how many metal sheets does the object consists of and what are their exact positions. There were also a few technological phenomena which were less visible, such as the embossing tool marks or the "serrated edge" at the middle. Moreover, the manufacturing technique of the metal sheets were not entirely clear due hammering marks were only visible on a few spots.
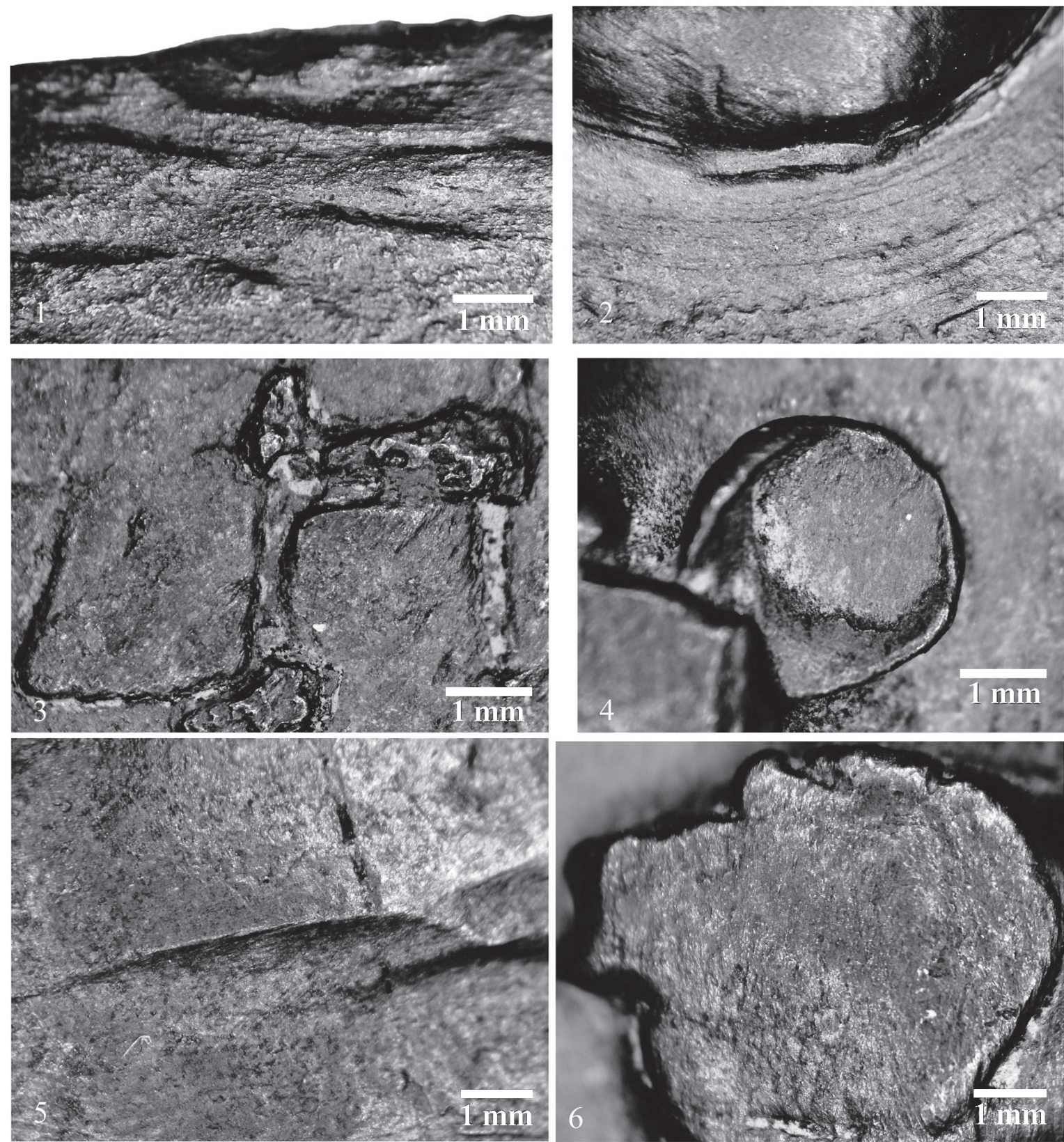

Fig. 2. Observations made during the microscopic examination (front view). 1: Hammering traces on the edge; 2: Imprint of the embossing tool around one of the smaller dots; 3: Crenellated joint; 4: Hammered smaller rivet head (II/1); 5: Oval-shaped hammer marks along the contour of the outer metal sheet circle; 5: Hammered greater rivet head (Microscopic images: J. G. Tarbay) 

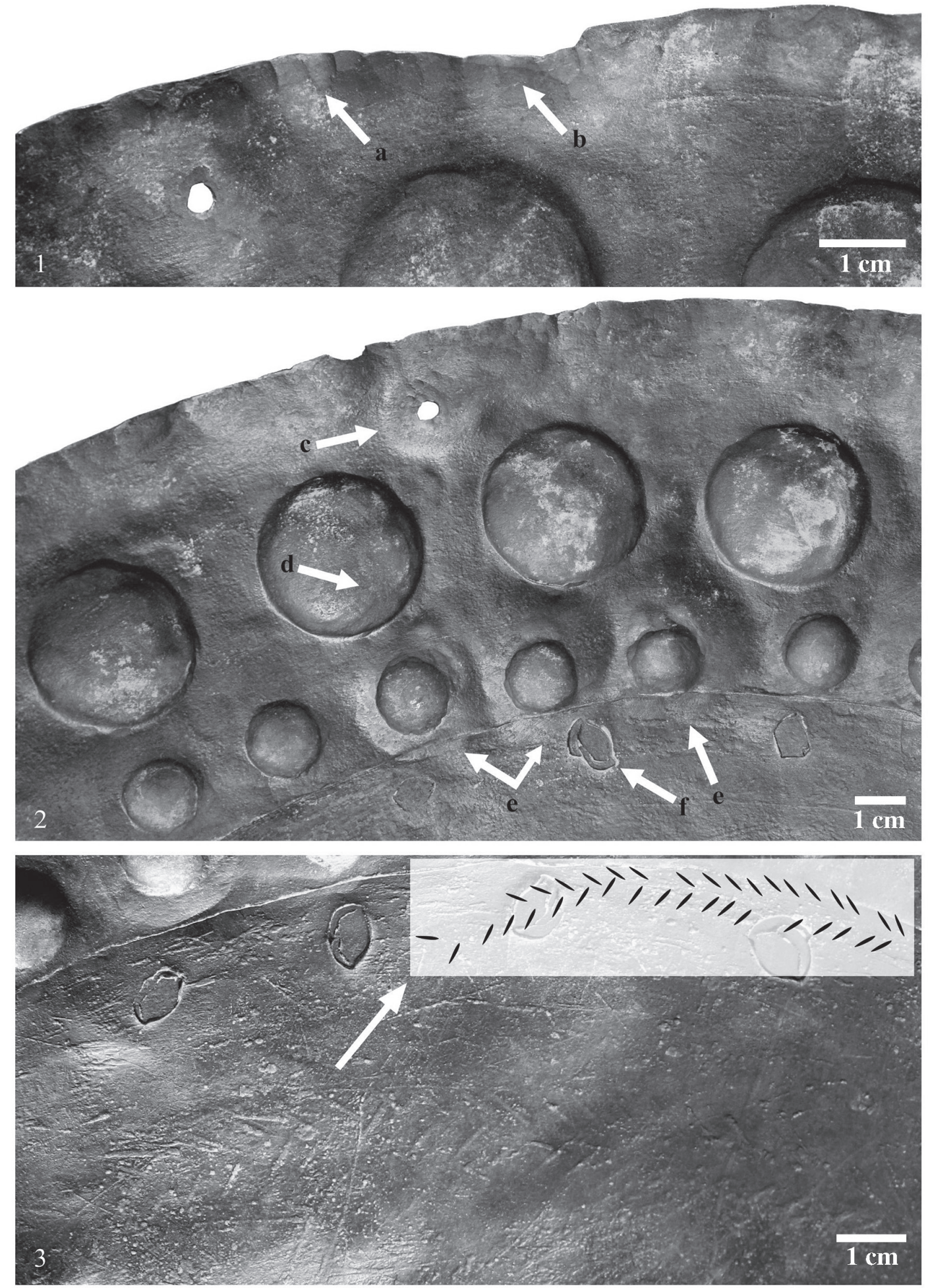

Fig. 3. Observations made during the macroscopic examination (bottom view). 1a: Hammered marks on the edge;

1b: Hammered damaged part; 2c: Imprint of a conical-shaped rivet; 2d: Imprint of the embossing tool on one of the greater dots; 2e: Imprint of embossing tool around the smaller dots (these imprint cover D metal sheet); 2f: Completely hammered rivet head;

3: Fishbone-like decoration (Photos and drawings: J. G. Tarbay) 


\subsection{X-ray Fluorescence spectrometry}

As a first step, due to the large dimensions and the complexity of the artefact, on-site measurements in the Hungarian National Museum were done in order to determine the elemental content using a handheld XRF device. As XRF is a surface analytical technique, and the ancient copper-based metal artefacts are covered with altered outer layer, the original alloy composition cannot be determined by this method. Taking into account the limits of the technique, ${ }^{11}$ our aim was the separation of the different sheet parts. The artefact, evenly covered by green patina was measured in 100 different points in two steps. The XRF results are listed in Table 1 in the Appendix. The detection limits of the elements in copper matrix are listed here: Ni 0.019 mass percent (m\%), Sn $0.06 \mathrm{~m} \%, \mathrm{Sb} 0.06 \mathrm{~m} \%, \mathrm{Fe}$ $0.012 \mathrm{~m} \%$, Pb $0.008 \mathrm{~m} \%$, Bi $0.049 \mathrm{~m} \%$ and $\mathrm{Zn} 0.07 \mathrm{~m} \%$.

At first we investigated the composition of both the front and the bottom of the different plates separable with naked eye. ${ }^{12}$ Figure 9 shows that the artefact consist of at least three sheets, and at the edge of two inner sheet two rows of rivets (I, II) can be observed. The rivets, arranged in these two rows were also measured. The rivets belong to sheet $D$ contained various elements. (Sheets' structure and numbering will be detailed later.) The outer (near to the edge of sheet $D$ ) and the inner side of the rivets showed different compositions. After a more careful microscopic observation of the hammered large rivets of sheet $D$ it was revealed that the outer row of rivets consist of two rivets (Fig. 2.4), which are different in size and in element content. The X-ray and neutron radiography images verified the XRF results.

All the parts were identified as copper-based metals, with less than 1 mass percent of $\mathrm{Fe}, \mathrm{Ni}, \mathrm{Sn}, \mathrm{Sb}, \mathrm{Pb}$ and $\mathrm{Bi}$ content. Presence of Sn and Sb were only detected in two parts of the repair sheets in the middle of the artefact. Based on the major and minor constituents $(\mathrm{Cu}, \mathrm{Sn}, \mathrm{Sb}, \mathrm{Fe}, \mathrm{Ni}, \mathrm{Pb}$ and $\mathrm{Bi}), 4$ main class can be distinguished within the parts of the object using the Agglomerative Hierarchical Clustering (AHC) in XLSTAT statistical software for PC (Fig. 4). ${ }^{13}$ The dendrogram of the XRF results $B 1$ and $C$ sheet belong to the first class (C1), together with the front side of rivets of $C$ sheet and the front side of the larger rivets of sheet $D$. The rear side of the large $D$ sheet rivets and $D$ sheet itself belong to the second class (C2). From all the four class, $C 1$ and $C 2$ are the most similar to each other. Third class (C3) contains the sheet A and the small rivets of $D$ sheet. B2 and B3 are the most different from the other parts, they form the forth class (C4).

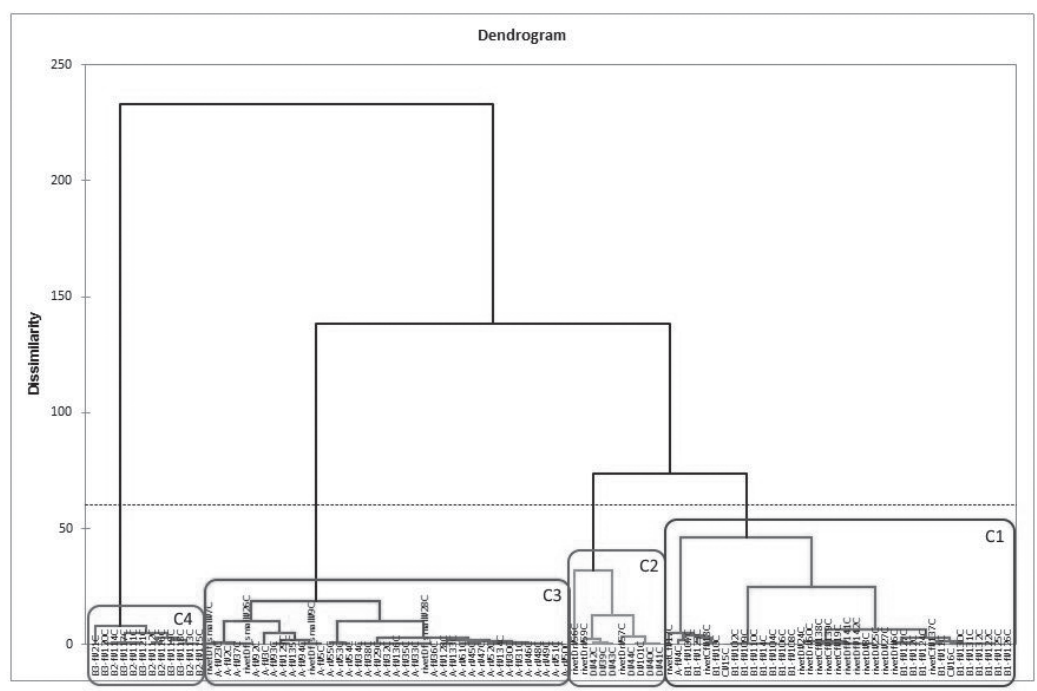

Fig. 4. Results of the Agglomerative Hierarchical Cluster (AHC) analysis (Cluster: Boglárka Maróti)

\footnotetext{
${ }^{11}$ Giumlia-Mair 2005.

${ }^{12}$ After the complex layered structure of the artefact were revealed by microscopic observations and radiography, the object was examined again by XRF, particularly to the inner part.
}

${ }^{13}$ AdDinsoft. 2016. XLSTAT 2016. 


\subsection{X-ray and Neutron Radiography}

The resulting images showing interesting features are presented in the following section. The darker the colour the stronger is the attenuation of that area. According to the XRF results the elemental composition of the object is quite homogeneous from the viewpoint of the $\mathrm{X}$-ray or neutron radiography therefore it can be stated that the darker colour means thicker material. The object was not cleaned before the irradiations, thus external contamination (if exists) could affect the attenuation of the neutron and the X-ray beam, and as a result, artifacts could appear in the final images. This is true for invisible contaminations too, e.g. for materials stuck between the metal layers.

Since sectional images were acquired during the measurement, there was an intention to produce a spectacular, composite image showing the entire object produced by stitching together the individual overlapping images. Apart from some distortions of such composite images originating from the stitching process (e.g. some unsharpness and geometrical biasing), we could get valuable information about the structure and the condition of the object. In our case, the composite image was produced stitching together the individual overlapping X-ray images (see Fig. 5.1) because stitching neutron images gave too many distortions.

Both the composite $\mathrm{X}$-ray and the individual neutron image of the object show many lighter spots distributed more or less evenly (see Fig. 5.1-2, Fig. 7.1) which were not visible neither to the naked eye nor under microscope. These spots occur even in the one-layer-thick rim implying thinner material at these regions. Their forms are slightly irregular, round or oval-shaped (Fig. 7.2.a). Such traces could be the consequence of repeated hammering which was hypothesized by the research as a crucial manufacturing technique of greater metal sheet artefacts such as shields and cauldrons. ${ }^{14}$
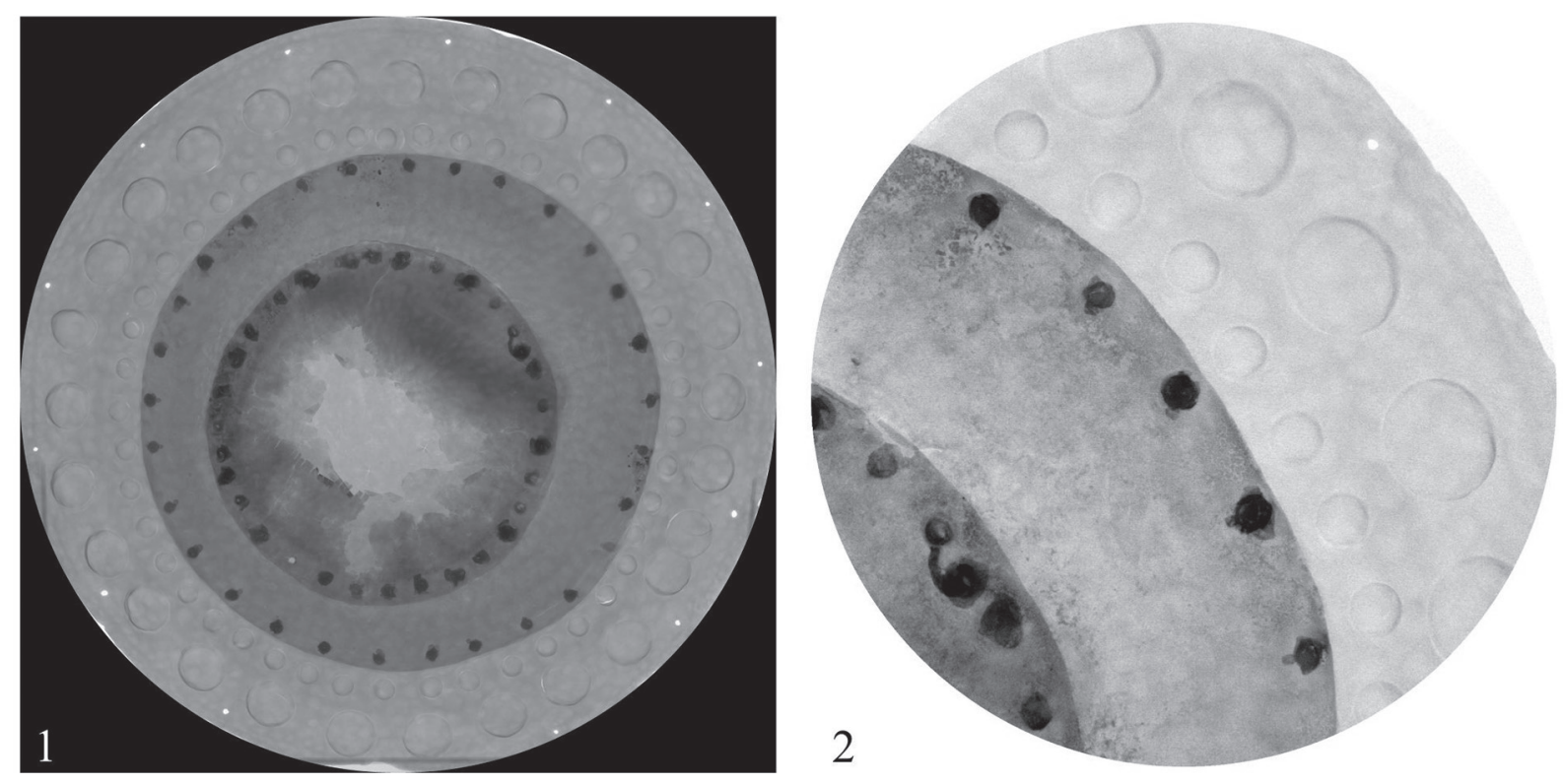

Fig. 5. 1: The composite X-ray radiography image showing the entire object, which was stitched together using the individual overlapping images; 2: An individual neutron radiography image showing a part of the object (Images: Zoltán Kis)

The rivets holding the layers together are the darkest spots on the images (See Fig. 5.1-2). This comes from the fact that their material is quite opaque for both the X-ray and neutron radiation, and they are longer along the beam compared to the added thickness of the layers they hold together. Moreover, at several rivets the images show a "twin" structure, i.e. a possible use of a larger and a smaller rivet to join the layers together.

\footnotetext{
${ }^{14}$ See NoRThOver 2010; UCKELMANN 2011. Similar hammering marks were identified by radiography on the Pergamon shield from the Antikensammlung Berlin. See Peltz Abb. 14.
} 
Both types of the images (see Fig. 5.1-2) show different material thicknesses according to the layered structure of the object. A detailed study of the layered structure can be seen in Fig. 6, which is an X-ray radiography of a part of the object. From outside to inside (i.e. from the rim to the middle point) the number of the overlapping layers is increasing reaching at least 3, but probable 4 layers in the middle. The change in the number of the layers can be followed as e.g. gray scale profiles along a selected Region Of Interest (ROI). To make such a profile, a ROI is selected as one can see the white rectangle in Fig. 6.1. and Fig. 6.3. The gray scale profile along the long side can be seen in Fig. 6.2. The steep changes along the profile marks where the number of the layers changes. Based on this we can count 4 layers, which were not visible neither to the naked eye nor under microscope. Because the energy spectrum of the X-ray tube and the bulk elemental composition of the sheets is not known precisely, the exact layer thicknesses cannot be calculated reliably.
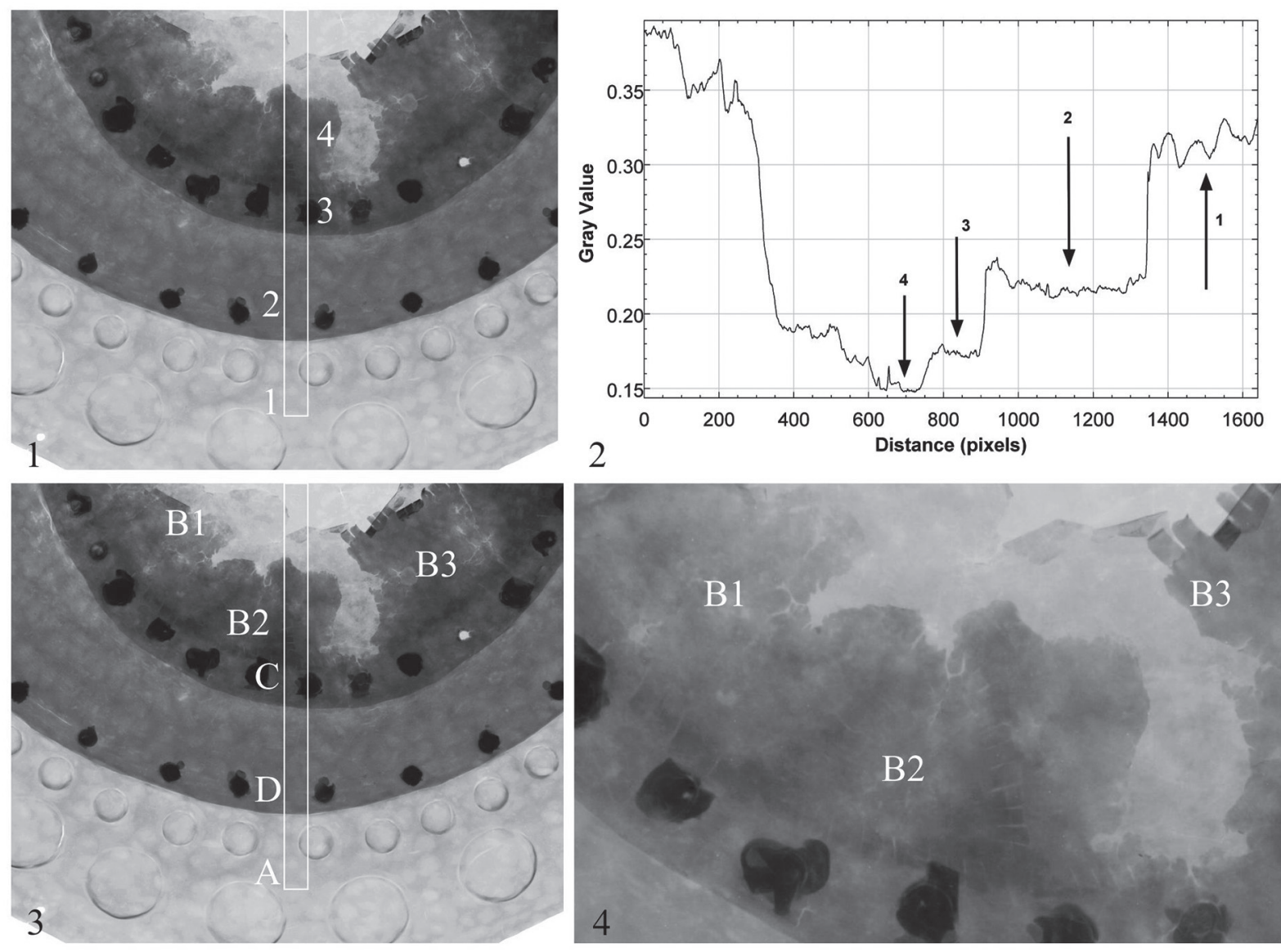

Fig. 6. 1: The X-ray transmission image of a part of the object with the ROI (white rectangle) selected; 2: The grayscale profile along the long side of the ROI. The 0 pixel position refers to the centre of the object. Based on this we can count 4 layers; 3: Different metal sheet parts on the X-ray image, 4. Crenellated joint patches (Images: Zoltán Kis)

A more detailed study of the images reveal several type of fine structures due to various impacts on the objects (e.g. embossed tools marks, hammering of the rim, crenellated joint). The embossed decorations were created probable by a punching tool. Around some of them the circular shaped impact of the tool (embossed tools marks) could be clearly noticed (Fig. 7.2.c-d). Moreover, the dense hammering spots of the rim can be seen as well (Fig. 7.2.b). In Fig. 7.4 one can see two impact marks in the central part of the object (see black arrows) an in

${ }^{15}$ Similar crenellated joint was identified by X-ray images on a Byzantine trumpet. See ANHEUSER 2009, Fig. 3.95. 

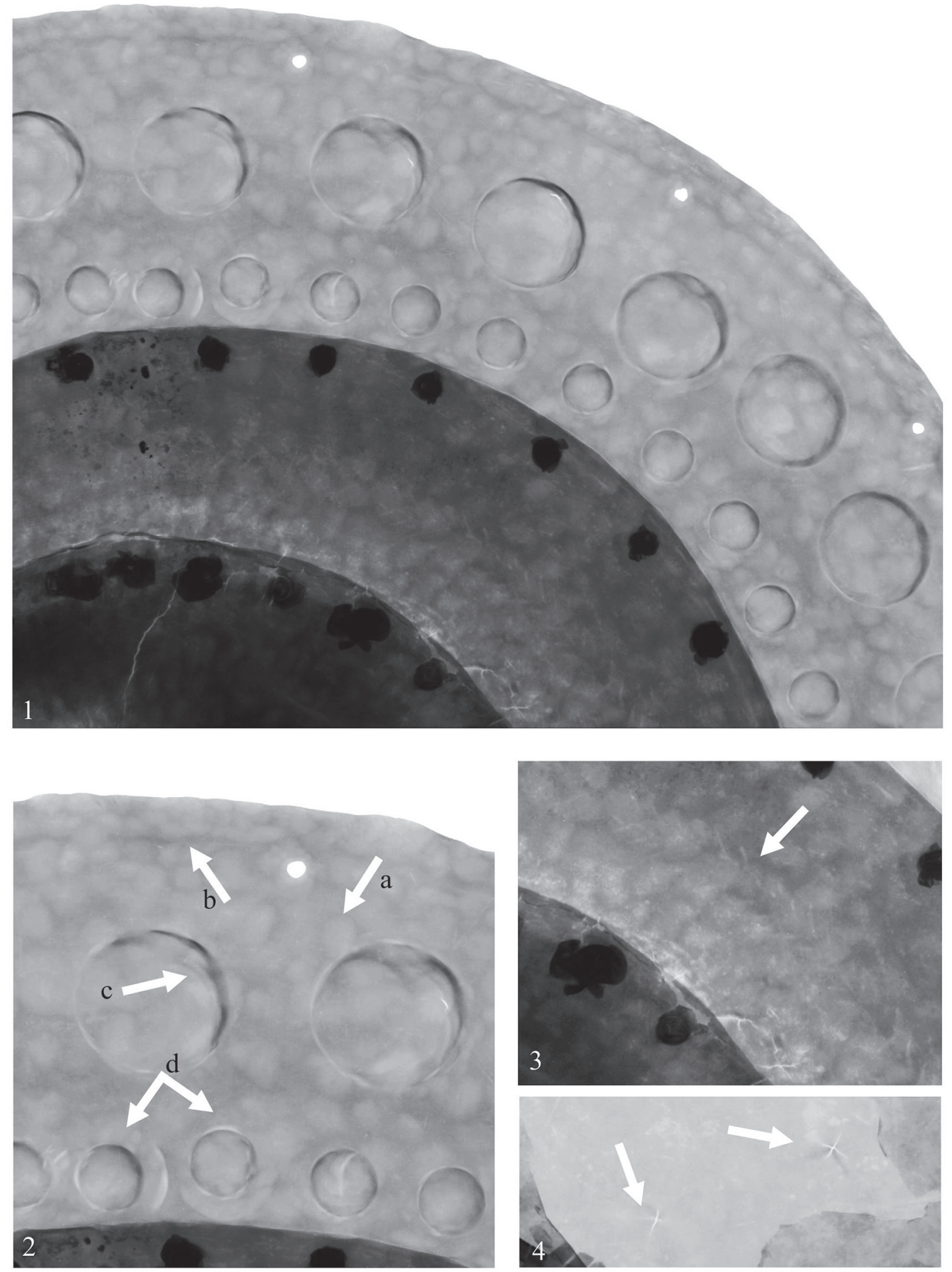

Fig. 7. 1: The X-ray transmission of the object showing dense hammering in concentric circles on the entire surface of the object; 2a: An oval-shaped hammering mark; 2b: Hammering spot of the rim; 2c: Different traces of punching tools; 3: Fishbone-like pattern; 4: Two impact marks in the central part of the object (Images: Zoltán Kis) 
Fig. 6.4. the "serrated" like structure of the crenellated joint technique. ${ }^{15}$ This type of joint is clearly visible between the sheets marked B2 and B3. The joint is less recognizable between the sheets B1 and B2, where only a darker stripe is visible. These joints and the crenelated joint next to the rivets form the triangular-shape B2 sheet. The fishbone-like decoration which was identified by macroscopic images also has become visible (Fig. 7.3).

An even more interesting part of the object can be seen in Fig. 8.1-2. A part of the object, e.g. where the rim and the adjacent layer is held together, could contain from outside invisible materials, which are different compared to the object's own material. There are darker spots, which give contrast in both the X-ray and the neutron images (arrows labelled by 1 in Fig. 8.1-2). These are presumably the broken-down parts of the rivets. There are darker spots, which give contrast in the X-ray image, without giving contrast in the neutron image (arrows labelled by 2 in Fig. 8.1-2). These could be materials with higher atomic number (e.g. lead), which have high and low attenuation for X-rays and neutrons, respectively. There is a darker spot, which gives contrast in the neutron image, without giving contrast in the X-ray image (arrow labelled by 3 in Fig. 8.1-2). This could be an organic material.
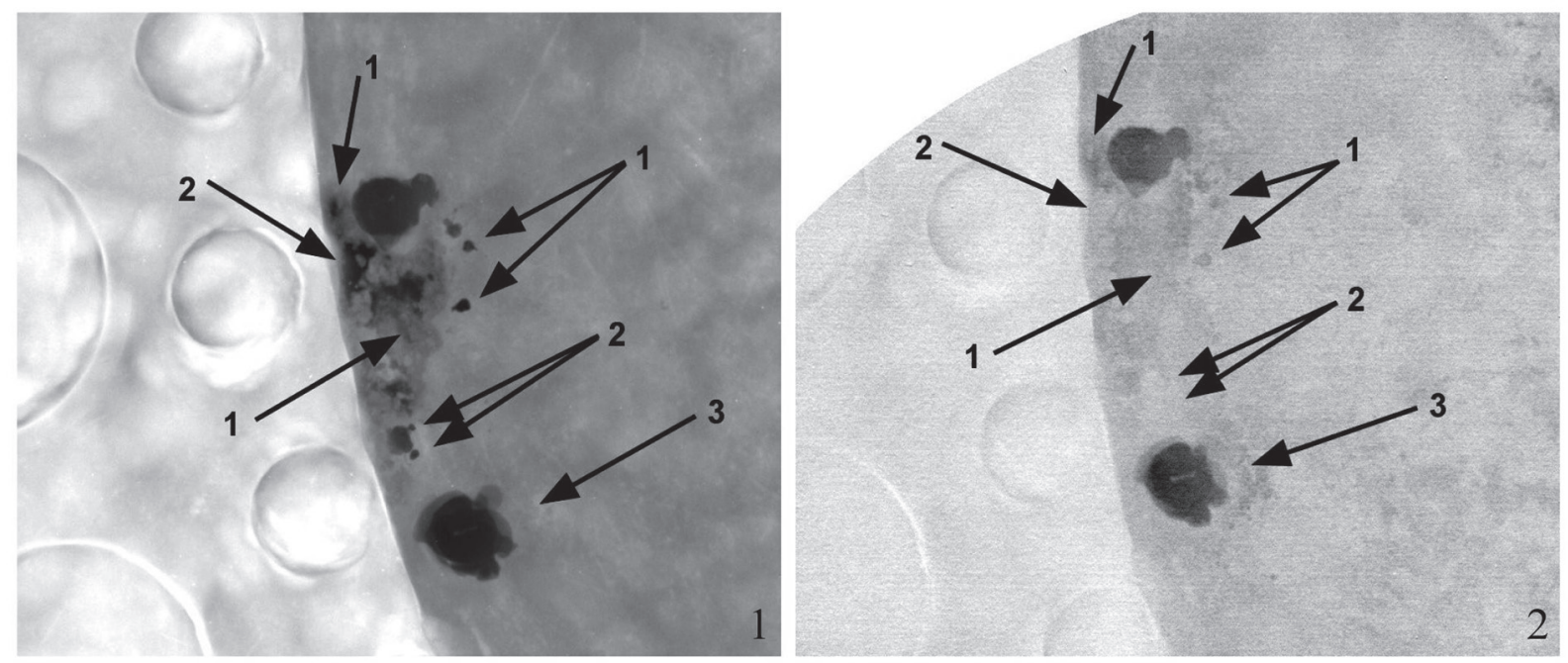

Fig. 8. A part of the shield around some rivets, e.g. where the rim and the adjacent layer is held together, could contain invisible materials, which are different compared to the shield's own material. 1: X-ray transmission image of the area; 2 : Neutron attenuation image of the area. One can see the various labelled spots around the rivets (see text) (Images: Zoltán Kis)

\subsection{The structure of the artefact}

The parallel use of four different analyses allowed us to give a detailed technological characterization of this unique artefact. The X-ray images clarified adequately the manufacturing technique of the object's metal sheet parts. Based on the shape of tool imprints, each discs gained its final form through repeated hammering.

Furthermore, the complex metal sheet structure of the artefact was revealed. It consists of four main metal sheet discs $(A, B, C, D)$. The largest disc replaced by multiple metal sheets $(B 1, B 2, B 3)$. These patch-like parts with serrated edges can be identified as traces of the so called crenellated joints; a special metalworking technique, which was used for both repairing and manufacturing metal sheet objects. ${ }^{16}$

An additional metal sheet disc $(C)$ was attached to the backside of the object by a circle of rivets $(I)$. These riveting penetrated disc $B$ which proves that this was the next repairing phase. Later, sheet $D$ with fishbone-like decoration was riveted onto sheet $C$ and $A$ from the backside. All analyses suggest that this circle of rivets consisted of larger (II) and smaller ones (II/I). After the riveting of discs $C$ and $D$, their contours were hammered on sheet $A$, which has well-visible traces on microscopic images. According to macroscopic observations and radiographic im-

${ }^{16}$ It is common that the crenellation was combined with soldering, but the presence of solder was not found by the aid of applied methods. See van DER HeIDE 1991, 129-130, Fig. 6; MundeL
Mango-Bennett 1994, 474-477, Fig. 15.5, Fig. 15.6; NAgY-Tóth 1990, 22, Fig. 3. 
ages, some embossing tool imprint of the inner dots overlay sheet $D$ which indicates that this decoration was made after the riveting of sheet $D$. Another possibility is that an original, larger embossed decoration was modified to a smaller one. The impact marks in the middle of the object are also interesting. If they are prehistoric in origin, these could suggest that the middle part of the object was exposed to some sort of damages, which could explain why this part was repaired so many times. The perforated edges of sheet $A$ are also important as their appearance indicates that the artefact is incomplete and it was most likely the part of a larger object.

\section{ROUND SHIELD OR CAULDRON?}

\section{THE DATING AND INTERPRETATION OF THE ARTEFACT}

Due to the unknown context and unique form of the artefact, the definition of its exact function is challenging. However, its detailed technological characterization provided significant amount of data that helped us to find finer typological aspects for its function and chronological position. The overall technological character of the bronze sheet object, especially the embossed decorations shows close similarities with the metal sheet products from the LBA ( $\mathrm{Ha} \mathrm{B}$ ) and EIA. Based on typological and technological evidences two types of interpretation (round shield or cauldron) are plausible.

\subsection{Round shield?}

During the very first examination of the object, it was interpreted as a LBA-EIA bronze round shield, based on its relatively flat body and characteristic embossed decoration. Bronze shields have appeared in the archaeological material at the earlier stages of the LBA (Br D-Ha A1) in Continental Europe, along with other defensive weapon types (helmet, cuirass, greaves) and sets of other prestigious metal vessels. ${ }^{17}$ The distribution of these exclusive metal products shows clear interregional features, very similar pieces were found even in the most distant parts of Europe ${ }^{18}$ According to archaeological experiments and metallographic analysis, these bronze round shields were hammered out from a cast copper alloy disc. The raw cast blank was flattened out into a metal sheet by timeconsuming hammering and annealing. ${ }^{19}$ In some cases macroscopic traces of hammer marks on LBA shields proves this process. Regardless of their type, almost all of them have a shield boss and a rolled-over rim, which serves to strengthen the most vulnerable part of these defensive weapons. ${ }^{20}$ Another main formal characteristic is the grip that was riveted onto the backside. ${ }^{21}$ Their Iron Age counterparts shows many similarities and except from some minor formal, stylistic and technological traits they were made in the same way. ${ }^{22}$

In respect of the analysed object's dimensions, such as its diameter, weight and thickness, it correlates with the average data of the LBA and EIA round shields. ${ }^{23}$ The embossed decoration which consists of two rows of bosses is also one of the most common pattern on shields. ${ }^{24}$ If the repaired damages of the edge (Fig. 3.1) and the two impact marks in the middle were not recent in origin (Fig. 7.4), then they can also confirm the shield hypothesis. However, if we take a closer look at the LBA and EIA round shields from Europe, there are only a few and quite distant parallels of this analysed object. These are the so called Athenry-Eynsham type bucklers, ${ }^{25}$ for which's chronological position is less certain as all of them are stray- or river finds. Based on stylistic aspects they were associated with the Penard (Ha A1-Ha A2) and Wilburton-Wallington Period (Ha B1). ${ }^{26}$ It should be emphasized that their main distribution area is far from the possible find spot of this object, moreover the appearance of these bucklers are strictly limited to the British Isles and Ireland. ${ }^{27}$ The only similarities between this

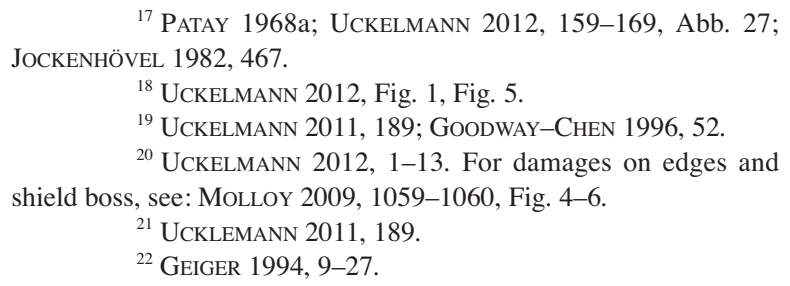




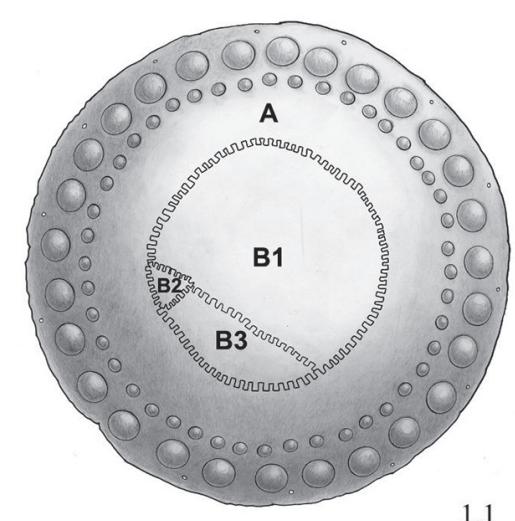

1.1

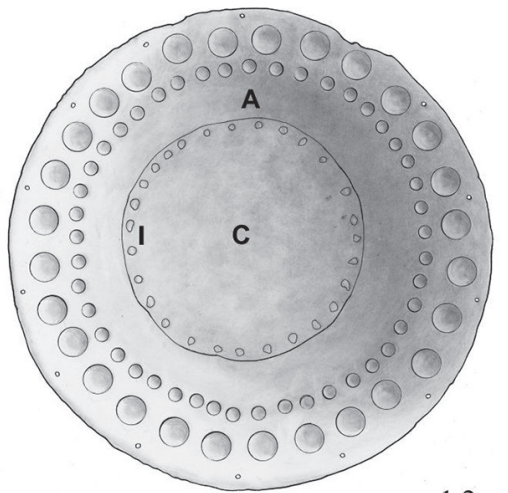

1.2

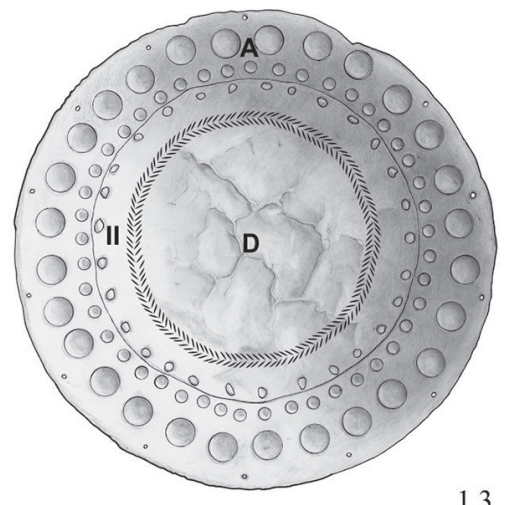

1.3

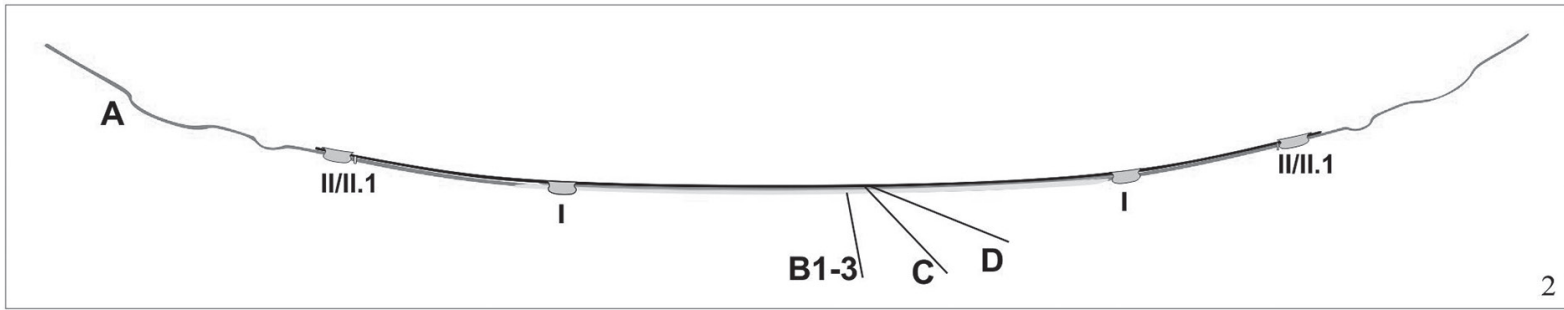

Fig. 9. 1. The identified metal sheet parts of the object. 1.1: Front view; 1.2-1.3: Bottom view; 2: Cross-section (see text) (Drawings: Anna Mária Tarbay and J. G. Tarbay)

distant LBA shield group and looted object is their relatively large size of embossed decoration and the lack of rolled-over rim. ${ }^{28}$ In the EIA of Eastern Europe and the Balkans only bronze phalerae can be found which were interpreted as shield bosses but their technological and stylistic character significantly differs from the analysed object. ${ }^{29}$ The same can be stated in regard of the round shields from Greece and Italy. ${ }^{30}$ Only the shield boss from Banská Bystrica should be mentioned because of the lack of rolled-over rim and its perforated edges that makes it similar to the looted artefact. ${ }^{31}$

In sum, the form and style of the average LBA and EIA round shields greatly differs from the analysed specimen. The shields, which seem to be similar to the looted artefact, are from distant parts of Europe. The lack of shield boss, rolled-over rim and the uncharacteristic riveted reparations are all against the defensive weapon interpretation.

\subsection{Bottom of a cauldron}

At the end of the looted artefact's examination, its overall technological character raised a much more probable interpretation. The riveted multiple repairing, the perforated edges, but even the diameters of the objects are similar to the bottom parts of the LBA and EIA bronze sheet cauldrons.

These large ceremonial vessels were used for cooking or boiling liquids, according to burnt traces on some specimens and written sources from the Eastern Mediterranean, Aegean and Early Middle Ages. They were associated with alcohol and even drug consumption, but their symbolic values (e.g. wealth, redistributive power, generosity) and magical properties were also stressed out based on later written sources. However, cauldrons were more likely used in collective feasting ceremonies for meat cooking. ${ }^{32}$ In the Atlantic, cauldrons distributed in the same area as other parts of the feasting equipment, such as flesh-hooks, spits, bowls, stands. ${ }^{33}$ From these, flesh-

${ }^{28}$ UCKLEMANN 2011, 191. Another less certain parallel can be found in the territory of Italy within the group of miniature round shields which appeared as grave goods in elite burials (e.g. Quadrato di Torre Spaccata Grave 1) dated to the $11^{\text {th }}$ and $10^{\text {th }}$ century BC (Protovillanova Period). UCKELMANN 2011, 89-92, Abb. 10.

\footnotetext{
${ }^{29}$ See EgG 1996; Kemenczei 2009, 50-51, Anm. 403-408.

${ }^{30}$ GEIGER 1994.

${ }^{31}$ BARTÍK 2001, 81-82, Obr. 1-2.

${ }^{32}$ GREEN 1998; ARMADA 2011, 168.

${ }^{33}$ ARMADA 2011, 168, Fig. 9.1.
} 
hooks are the most important because of their combined deposition with cauldrons and appearance in Eastern Europe. $^{34}$

The manufacturing of cauldrons shows similarities with the shields. Development of the metal sheet parts started with a cast blank, ${ }^{35}$ which went through a series of cold working and annealing until it reached its required form. ${ }^{36}$ The final product was constructed to a circular bottom and wall sheets. These different parts were assembled by rivets. Depending on the place of origin different kind of handles (strapless and ring handles, straped-handles etc.) were also attached to the vessels' rim. ${ }^{37}$ It has been observed on many Atlantic cauldrons that their damaged bottom was replaced or repaired with different circular disc and rivets (e.g. Fig. 10.6). No wonder, this section was not just simply the most vulnerable part of the vessel but it was constantly exposed to intensive heat. ${ }^{38}$ As Sabine Gerloff noted, these repairs are "much cruder workmanship" which seem to be carried out by "unskilled craftsmen". ${ }^{39}$ This "cruder workmanship" is also visible on the analysed object. While the middle part was repaired with a very fine crenellated joint technique (B1-3 sheets) (Fig. 2.3, Fig. 6.4) the workmanship of the C and D sheets are less sophisticated.

Cauldrons have appeared in the BA in different territories of Europe: 1. Mycenae, 2. Atlantic, 3. Carpathian Basin, 4. Northern coast of the Black Sea (Fig. 10.1-4). Although their manufacturing techniques show similarities, they represent different chronological periods, and their origin and technological connection with each other is not yet fully understood. The first cauldron types made of multiple, riveted metal sheets (Variant A and B) have appeared in the Aegean. The find from Tylissos (Crete) was dated to the MM III-LM I, the vessels from the Mainland and the pieces from the Mycenaean shaft graves were dated to the LH I. ${ }^{40}$ Even though these are the oldest finds, it is not entirely clear how they influenced the metal vessel production of other European regions. Some researchers argued that this sheet-metal working technique could have find its way to the Carpathian, while others, like Bochkarev completely rejects the Mycenaean origin in the case of the Eastern European types, and stated that this metal sheet technique was already present in Eurasia between the $3^{\text {rd }}$ and $2^{\text {nd }}$ millennium $\mathrm{BC} .{ }^{41}$ Most of the cauldrons were found in the Atlantic. These globular-shaped, large metal vessels distributed in the territory of Ireland, Britain, France and in the North-western part of Iberia. Their first specimens (Class A0) have appeared in the Appleby/Penard 1/Rosnoën period (1300 BC) and their production lasted through the Iron Age A/Dowris C period (600 BC). ${ }^{42}$

In East Central Europe only a few cauldrons are known. The earliest was found in the Austrian Sipbachzell hoard. ${ }^{43}$ The Sipbachzell type cauldron which has only one known specimen from the above mentioned hoard, has a globular outline and two strap handle, similar to the Kurd buckets. ${ }^{44}$ Based on these typological features and the chronological position of the hoard, it was dated to the Br D-Ha A1 period. ${ }^{45}$ The specimens known from the Carpathian Basin are younger. Three cauldrons of the so called Sümeg type have been found in Hungary, in the SümegÚjhegy (Fig. 10.2) (6) $^{46}$ and Várvölgy-Uzsabánya ${ }^{47}$ hoards. Pál Patay dated the first to the Ha B1 period and interpreted this type as a "local product". ${ }^{48}$ The list of the Sümeg type cauldrons was expanded by some less certain fragments from the $2^{\text {nd }}$ Bodrogkeresztúr ${ }^{49}$ hoard and other East European assemblages. An uncertain metal vessel is also known from the Ha B1 Corneşti (Romania) hoard which was reconstructed from a few parts by Mircea PetrescuDîmboviţa. ${ }^{50}$

${ }^{34}$ GERLOFF 2010, 116. For flesh hooks, see: HundT 1953; VON BRUNN 1953; JÖCKENHÖVEL 1974; NEEDHAM-BOWMAN 2005. For hooks from the territory of Hungary: ILON 2002, 158.

${ }^{35}$ A casting mould which can also be associated with metal sheet vessel manufacturing can be found in Dolánky (Czech Republic). Kytlicová 1991, 96, Taf. 12.62; 137, BLAŽEK et al. 1998, 67, 137, Taf. 9.8 .

${ }^{36}$ See NORTHOVER 2010.

${ }^{37}$ Gerloff 2010, 41-42, Fig. 2.

${ }^{38}$ Gerloff 1986, 87; GERLOFF 2010, 115-116. Carpathian example for repairing: Sümeg. SZENTHMÁRTONI DARNAY 1889, 262.

${ }^{39}$ Gerloff 1986, 87; Gerloff 2010, 42.

${ }^{40}$ Mätthaus 1980, 85.

${ }^{41}$ GerLOFF 1986, 106; БОЧКАРёв 2010, 186, 204-205.

${ }^{42}$ Gerloff 2010, 333-343, Pl. 167; Armada 2011, Fig. 9.1; BORDAS 2016, 147, Fig. 21.
${ }^{43}$ HöGLINGER 1996, 72, Taf. I.1.

${ }^{44}$ GERLOFF 2010, 391.

${ }^{45}$ GerLofF 2010, 391. Ha D3 specimens are also known from Austria (Hallstatt, Hallein) but their form differs greatly from the standard cauldrons. PRÜssING 1991, 76, Taf 70/71.270, Taf. 71.271.

${ }^{46}$ SZENTMÁRTONi DARNAY 1889, 262, T. I-II; DARNAY 1899, 20-21, T. VIII, T. IX; PATAY 1990, 80, Taf. 64.114.

${ }^{47}$ LÁszló 1982, 27; PATAY 1990, 80, Taf. 66.145A.

${ }^{48}$ Patay 1990,80

${ }^{49}$ Hampel 1886, T. XCVI.8; Patay 1968b, 71, 81, Fig. 15.1, Fig. 16; KemenCZei 2003, 26, Taf. 7.21; Gerloff 2010, 390.

${ }^{50}$ Petrescu-Dîmboviţa 1978, 141-142, Taf. 230.46, 4951; SoroceAnu 2008, 194, No. 136.a-k, Taf. 49.136.a-k. A fragment from Băleni was also associated with cauldrons. PETRESCU-DîMBOVIŢA 1977, 73-74, P1. 87.9; БОчКАРЁв 2010, 207. 

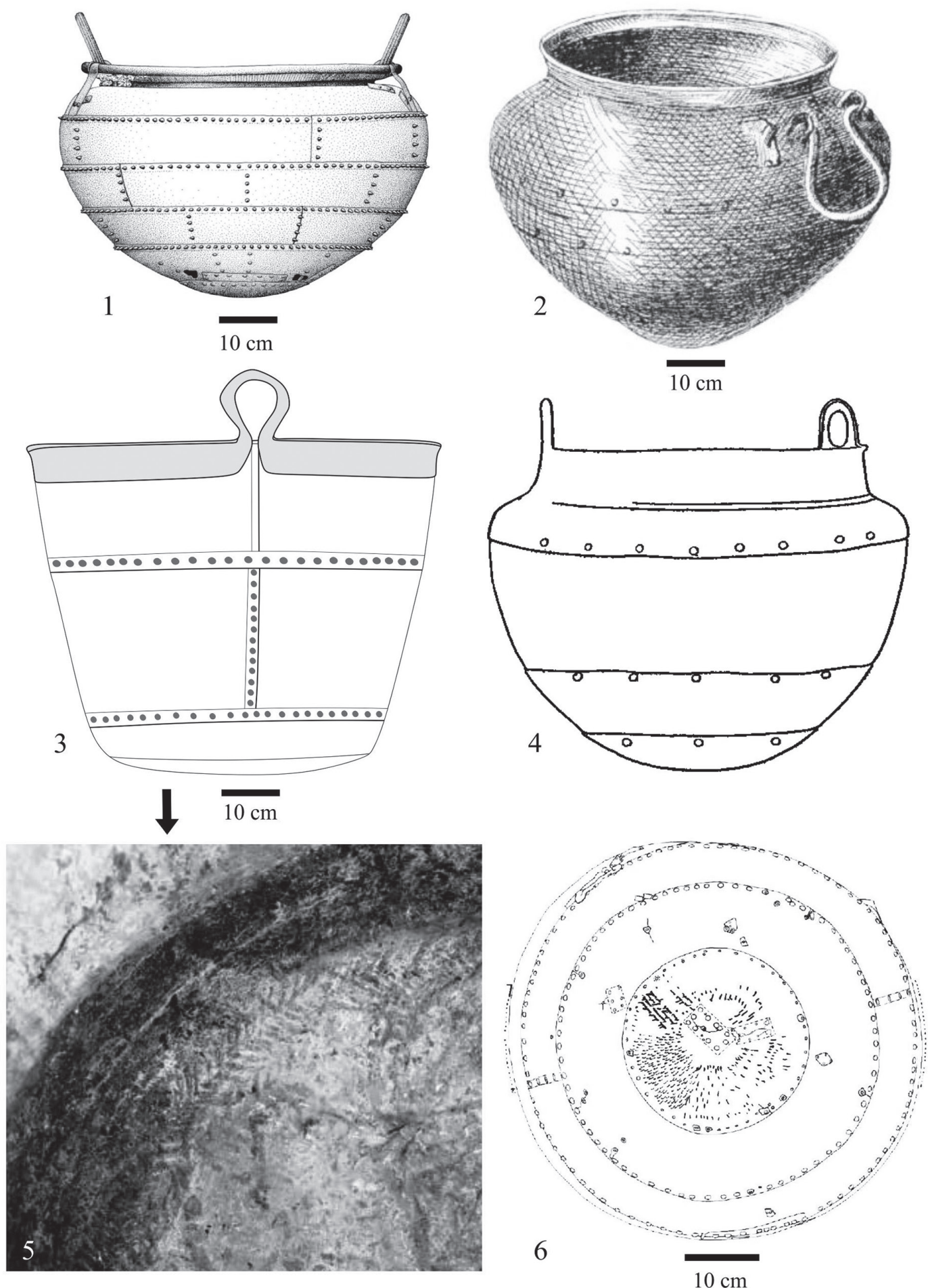

Fig. 10. Cauldrons from different territories of Europe. 1: An Atlantic cauldron from Ballyshannon, Ireland (Gerloff 2010, Pl. 53.33.b); 2: A cauldron from Sümeg, Hungary (Szentmártoni Darnay 1889, T. II); 3: The metal vessel with iron handle from Lysianska, Ukraine (after Клочко-Козыменко 2017, илл. 2); 4: The cauldron from Novopavlivka, Ukraine (Кривцова-Гракова 1955, рис. 31.3);

5: Fishbone-like pattern on the bottom of the metal vessel from Lysianska (Клочко-Козыменко 2017, илл. 2.6); 6: Repaired bottom of a cauldron from Raffrey Bog, Ireland (Gerloff 2010, Pl. 93.56) 
Groups of several different cauldron-like vessels, made of multiple riveted metal sheets can be found in the eastern part of the Carpathian Basin. Their primary distribution area is the Northern coast of the Black Sea. More precisely, the territory of Southern Moldova, Volga and the Ural region, Volhynia, but specimens are known from Romania, Serbia and Central Kazakhstan, as well. ${ }^{51}$ Throughout the history of research several different classification schemes were proposed by the Eastern European researchers, ${ }^{52}$ the latest and most detailed was carried out by V. S. Bochkarev. ${ }^{53}$ According to his typo-chronology, the eastern cauldrons can be divided into 3 different groups (I.-III.) based on fine typological features. The earliest is the I. group which appeared in the LBA (Periode III/Br D-Ha A1), the latest is the III. group, which correlates with the end of the LBA and the EIA (Periode IV-V/Ha A2-B1-Ha B2/3-Ha C1) ${ }^{54}$ From typological point of view, these metal vessels differ greatly from the Carpathian, and Atlantic ones. These cauldrons are often equipped with a base, their general shape is more elongated, the technique and shape of the handles are also different, for instance later ones are often equipped with iron handles. ${ }^{55}$ The reason why this vessel group should be mention here is because of two specimens from Ukraine. The first one is the cauldron from Novopavlivka (Kirovohrad Oblast), which was considered to be atypical in this region (Fig. 10.4). ${ }^{56}$ The lack of base and the shape of this round-bottomed specimen is more similar to the western cauldron types, and also to the analysed metal sheet object. The second is a new find from Lysianska (Cherkasy Oblast) in Central Ukraine. This small situla like vessel ${ }^{57}$ is equipped with iron handles and made of different riveted sheets. The most interesting part is its bottom which is decorated with the same fishbone-like pattern as our specimen (Fig. $10.3,5){ }^{58}$ At first glance, these parallels seem to be quite far from the suspected finding place of the analysed object. But we must not forget that the distribution area of the eastern cauldrons cover the territory of the North Balkans. Fine example of this is the handle fragment which was found in Serbia, in the hoard from Mesic (Stufe II/Br D-Ha A). ${ }^{59}$ Except from the above mentioned fragment, we are not aware of any metal sheet cauldrons from the North Balkans between the LBA and EIA.

In conclusion, different technological aspects can support the cauldron function: 1.) The artefact consists of different circular metal sheets joint by riveting which is a very common reparation technique for cauldrons but uncharacteristic for LBA and EIA shields. 2.) Crenellated joint is an impermeable repairing technique which is a perfect proof against leaks. ${ }^{60}$ Considering the completely smooth surface and flattened rivets on the backside of the artefact, later repairing phases also sought to archive a similar effect. 3.) The average size and convex shape of the artefact also correlates well with the larger round-bottomed cauldrons. 4.) Decoration of disc D shows similarities with an EIA large metal vessel made of different metal sheets from Lysianska.

The dating of the object is much more problematic and without the context and the lack of exact parallels, it is still quite a challenge. One of the main evidence for prehistoric dating (LBA-EIA) is the embossed decoration, which is uncharacteristic for later periods. According to our knowledge, the crenellated joint repairing technique is unknown in the eastern part of Europe during the LBA, which could argue for later dating, however it raises the necessity for more detailed analyses on comparable metal sheet products from this region. The relative large size of the dots and the parallel of the fishbone-like pattern on the back could support the EIA dating.

\section{CONCLUSIONS}

In this study, a looted metal sheet artefact was characterized from technological point of view. As the results of the applied analyses technological hypotheses based on macro- and microscopic observations were proved and explained in detail. It was possible to reconstruct, a complex metal sheet object which was repaired by different techniques (crenellated joints, riveting) during its prehistoric use-life. Combining the typological, stylistic and

187

${ }^{51}$ Dergačev 2002, 134-135, Taf. 107; БочкAPËв 2010, 2010,185

${ }^{52}$ With citations see DERGAČEv 2002, 134-135; БОчKAPËB

${ }^{53}$ БочкаРёв 2010, 180-208, Рис. 2-4, 6.

${ }^{54}$ The group II. partly overlaps with both (Periode IV/Ha А2-В1). БОЧКАРЁв 2010, 208.

${ }^{55}$ БОЧКАРЁв 2010, 188-192, рис. 2-4, 6.
${ }^{56}$ КРИвЦОВА-ГРАКОВА 1955,133 , рис. 31.3 ; БочкАРЁв 2010, 191, рис. 4A.

${ }^{57}$ Its dimensions are the following: Height: $47 \mathrm{~cm}$, Diamaters: 70 cm-40 cm. Клочко-Козыменко 2017, 218

${ }^{58}$ Клочко-Козыменко 2017, 221, илл. 2.6.

${ }^{59}$ РАШАЈСКИ 1975, 67, Т. LXII.15; БочКАРЁв 2010, 207, рис. 8.7.

${ }^{60}$ NAGY-Tóth 1990, 22. 
technological arguments allowed us to identify the artefact as a bottom part of a large cauldron, which was most likely a product at the end of the LBA or the EIA. Due to the lack of exact parallels it is hard to determine the object's possible find spot. Based on the route of the smuggler it could originate from the Balkans. However, considering international smuggling routes outside of the European Union other finding places are also possible.

The examination of the object is not finished yet. The following step of the research project is to determine the original alloy composition of the different sheets of the object. These data can be compared with the elemental concentration data of previously examined cauldrons, available in the literature. ${ }^{61}$ Due to the large dimensions of the object, PGAA measurement is not feasible but by measuring the carefully unpatinated surface using XRF equipment, and using destructive methods, such as NAA or ICP-MS the bulk elemental content can be obtained. Additional aim of the further research is the detailed and focused examination of the different sheet edges. The question is whether the crenellated joint, successfully identified in the present research, was supplemented by soldering or not. Time-Of-Flight Neutron Diffraction (TOF-ND) measurements are planned in order to reveal microstructural information of the object. This method is capable of providing information about the metal phase composition of bulky objects without sampling. The presence of certain phases in the metal may refer to the production and the usage of the object, ${ }^{62}$ e.g. cooking vessel.

\section{ACKNOWLEDGEMENTS}

We are most grateful to Ildikó Szathmári who generously permitted the publication of the find. We also would like to thank to Markus Egg, Katalin Jankovits, Zsolt Mráv, Biba Teržan, Géza Szabó and Gábor V. Szabó for the inspiring discussions, advices and critiques on the artefact's possible function and manufacturing techniques.

\section{REFERENCES}

AdDINSOFT. 2016. XLSTAT 2016

ANHEUSER 2009

ARMADA 2011

BARTíK 2001

BLAŽEK et al. 1998

БОЧКАРЁв 2010

BORDAS 2016

CRADDOCK 2009

DARNAY 1899
= AdDINSOFT. 2016. XLSTAT 2016: Data Analysis and Statistical Solution for Microsoft Excel. Paris 2016.

= K. ANHEUSER: Technological study of a Byzantine trumpet bell. Historic Brass Society Journal 21 (2009) 93-101.

$=$ X.-L. ARMADA: 9. Feasting metals and the ideology of power in the Late Bronze Age of Atlantic Iberia. In: Guess Who's Coming to Dinner. Feasting rituals in the prehistoric societies of Europe and the Near East. Eds: G. A. Jiménez, S. Montón-Subías, M. S. Romero. Oxford 2011, 158-183.

= J. BARTík: Štítová puklica z nezmánej lokality z okolia Banskej Bystrice (Die Schildbuckel aus einer unbekannten Fundstelle in der Umgebung von Banská Bystrica). ZbSNM 95 - Archeológia 11 (2001) 73-82.

= J. BLAŽEK-M. ERNÉE-L. SMEJTEK: Die bronzezeitlichen Gußformen in Nordwestböhmen. Beiträge zur Ur- und Frühgeschichtliche Nordwestböhmen 3. Nordböhmische Bronzefunde 2. Most 1998.

= В. С. БочКАРёв: Культурогенез и древнее металлопроизводство Восточной Европы [Culture Genesis and the Ancient Metal Production of Eastern Europe]. Санкт-Петербург 2010.

$=$ F. BorDAs: Trois nouveaux fragments de chauldrons des types de Cloonta et de Portglenone découverts dans le Nord-Ouest de la France. Notes préliminaires sur la découverte du dépôt de la Chapelle des Roches (Le Châtallier, Orne), Broze final atlantique 3. BSPF 113/1 (2016) 131-152.

$=$ P. CRADDOCK: Scientific Investigation of Copies, Fakes and Forgeries. Oxford 2009.

= K. DARnAY: Sümegh és vidékének őskora [Prehistory of Sümegh and its Vicinity]. ArchKözl 22 (1899) 5-85.

${ }^{61}$ Using the rapid non-destructive XRF analysis we obtained surface compositional data with more than 90 weight percent (wt\%) copper content. This high amount of copper and the presence of elements with soil origin as well as the low amount of typical alloying components (less than $1 \mathrm{wt} \% \mathrm{Sn}, \mathrm{Pb}$ ) can either be attributed to the thick corroded surface layer (cuprite, other cuprous oxides), or the mineralized state of the object.

Based on the literature data, cauldrons are tin-bronze objects usually with copper rivets. The comparison of the concentration data already available is rather difficult, due to the lack of detailed description of sample preparation procedures and the application of different analytical methods - e.g. EPMA, XRF, ICP-MS, NAA - with different probing volumes and surfaces.

If possible, we would like to measure additional cauldrons in order to obtain comparable composition data.

${ }^{62}$ KockelmanN-Kirfel 2006. 
DERGAČEV 2002

EGG 1996

GEIGER 1994

GERLOFF 1986

GERLOFF 2010

GiUMLIA-MAIR 2005

GOODWAY-CHEN 1996

GREEN 1998

HAMPEL 1886

VAN DER HEIDE 1991

HÖGLINGER 1996

HundT 1953

ILON 2002

JOCKENHÖVEL 1982

KEMENCZEI 2003

KEMENCZEI 2009

KIS et al. 2015

КРИвЦОВА-ГРАКОВА 1955

Клочко-Козыменко 2017

KoCKELMANN-KIRFEL 2006

KYTLICOVÁ 1991

LÁSZLÓ 1982

Mozsolics 1984

Mätthaus 1980

Mundell Mango-Bennett 1994

Molloy 2009

NAGY-TóTH 1990

NeEdHAM-Bowman 2005

NORTHOVER 2010

PATAY 1968a

PATAY 1968b

PATAY 1990

Peltz 2001

Petrescu-Dîmboviţa 1977

Petrescu-Dîmbovița 1978

PRÜSSING 1991
= V. DERGAČEV: Die äneolithischen und bronzezeitlichen Metallfunde aus Moldavien. PBF XX/9. Stuttgart 2002.

= M. EGG: Einige Bemerkungen zum hallstattzeitlichen Wagengrab von Somlóvásárhely, Kom. Veszprém in Westungarn. JRGZM 43 (1996) 327-352.

= A. GEIGER: Treibverzierte Bronzerundschilde der italischen Eisenzeit aus Italien und Griechenland. PBF III/1. Stuttgart 1994.

= S. Gerloff: Bronze Age class A cauldrons. Typology, origins and chronology. JAID 116 (1986) 84-115.

= S. GerlofF: Atlantic Cauldrons and Buckets of the Late Bronze and Early Iron Ages in Western Europe. With a review of comparable vessels from Central Europe and Italy. PBF II/18. Stuttgart 2010.

= A. GiUMLIA-MAIR: On surface analysis and archaeometallurgy. Instruments and Methods in Physics Research B 239 (2005) 35-43.

= M. GoodwAY-Y. CHEN: Fröslunda shields: Cymbals or symbols? Laborativ Arkeologi 9 (1996) 49-52.

= M. J. GREEN: Vessels of death: Sacred cauldrons in archaeology and myth. AntJ 78 (1998) 63-84.

= J. HAMPEL: A bronzkor emlékei Magyarhonban. I.: Képes atlasz [Antiquities of Bronze Age in Hungary]. Budapest 1886.

= G. J. VAN DER HEIDE: Brass instrument metal working techniques: The Bronze Age to the industrial revolution. Historic Brass Society Journal 3/1 (1991) 122-150.

= P. HöGLINGER: Der spätbronzezeitliche Depotfund von Sipbachzell/OÖ. Linz 1996.

= H.-J. HundT: Über Tüllenhaken und -gabeln. Germania 31 (1953) 145-155.

= G. ILON: Ein spätbronzezeitlicher Hortfund aus Szombathely (Steinamanger), Kom. Vas (Ungarn). Altertum 47 (2002) 149-169.

= A. JocKenHÖvel: Zu den ältesten Tüllenhämmern aus Bronze. Germania 80 (1982) 459-467.

= T. KeMEnCZEI: Der erste Bronzefunde von Bodrogkeresztúr. ArchÉrt 128 (2003) 17-49.

$=$ T. KemenCZEI: Studien zu den Denkmälern skythisch geprägter Alföld Gruppe. IPH 12. Budapest 2009.

= Z. Kis-L. Szentmiklósi-T. Belgya-M. Balaskó-L. Z. Horváth-B. Maróti: Neutron based imaging and element-mapping at the Budapest Neutron Centre. Physics Procedia 69 (2015) 40-47

= О.А. КРИвцОвА-ГрАКОВА: Степное Поволжье и Причерноморье в эпоху поздней бронзы [Volga steppe and the Black Sea Region in the Late Bronze Age]. МИА 46. Москва 1955.

= В. И. Клочко-А. В. Козыменко: Древний металл Украины [Ancient metal of Ukraine]. Киев 2017.

= W. KOCKELMANN-A. KIRFEL: Neutron diffraction imaging of cultural objects. Archaeometry Workshop (2006) 2006/III./2.

= O. KYTlicová: Die Bronzegefäße in Böhmen. PBF II/12. Stuttgart 1991.

= P. LÁszló: Várvölgy. RégFüz I/34 (1982) 27.

= A. Mozsolics: Ein Beitrag zum Metallhandwerk der ungarischen Bronzezeit. BRGK 65 (1983) 19-72.

= S. Mätтhaus: Die Bronzegefäße der kretisch-mykenischen Kultur. PBF II/1. München 1980.

= M. Mundel Mango-A. Bennett: The Sevso Treasure. Part One. JRA Suppl. Ser. 12/1. Ann Arbor 1994.

= B. Molloy: For Gods or men? A reappraisal of the function of European Bronze Age shields. Antiquity 83 (2009) 1052-1064.

= M. NAGY-E. Tóth: The Seuso cauldron. Is the Seuso Treasure from Hungary? Minerva 1/10 (1990) 22-23.

= S. NEEDHAM-S. BowmAn: Flesh-hooks, technological complexity and the Atlantic Bronze Age feasting complex. EJA 8/2 (2005) 91-136.

= P. NORTHOVER: Construction of Atlantic cauldrons and buckets. In: GerLofF 2010, 31-41.

= P. PATAY: Urnenfelderzeitliche Bronzeschilde im Karpatenbecken. Germania 46 (1968) 241-248.

= P. PATAY: Utóbronzkori bronzedényekről (On the bronze vessels of the Urnfield Age). ArchÉrt 95 (1968) 66-81.

= P. PATAY: Die Bronzegefäße in Ungarn. PBF II/10. München 1990.

$=$ U. PELTZ: Der makedonische Schild aus Pergamon der Antikensammlung Berlin. JbBM 43 (2001) 331-343.

= M. Petrescu-Dîmboviţa: Depozitele de bronzuri din România (Les dépôts de bronzes de la Roumanie). Bucureşti 1977.

= M. Petrescu-Dîmboviţa: Die Sicheln in Rumänien mit Corpus der jung- und spätbronzezeitlichen Horte Rumäniens. PBF XVIII/1. München 1978.

= G. PRÜSSING: Die Bronzegefäße in Österreich. PBF II/5. Stuttgart 1991. 
РАШАЈСКИ 1975

RobBiola-Blengino-Fiaud 1998

SEMENOV 1964

SOROCEANU 2008

SZABÓ 2013

SZENTMÁRTONI DARNAY 1889

SZILÁGYI et al. 2017

THOMAs et al. 2011

UCKELMANN 2012
= Р. РАшАлски: Остава Месић-Шупаја код Вршца [Ноard from Mesić-Supaja near Vršac]. In: Праисторијске оставе у Србији и Војводини I - Les Depots préhistoriques de la Serbie et de la Voivodine. Red.: М. Гарашанин, Н. Тасић. Fontes archaeologiae Serbiae I/1. Београд 1975, 63-68.

= L. Robbiola-J-M. Blengino-C. Fiaud: Morphology and mechanisms of formation of natural patinas on archaeological Cu-Sn alloys. Corrosion Science 39 (1998) 2083-2111.

= S. A. Semenov: Prehistoric Technology: An Experimental Study of the Oldest Tools and Artefacts from Traces of Manufacture and Wear. London 1964.

$=\mathrm{T}$. SOROCEANU: Die vorskythenzeitlichen Metallgefäße im Gebiet des heutigen Rumänien - Vasele de metal prescitice de pe actualul teritoriu al României. Cluj-Napoca 2008.

= G. SzABÓ: A dunántúli urnamezős kultúra fémművessége az archaeometallurgiai vizsgálatok tükrében - The Metallurgy of the Transdanubian Urnfield Culture in Light of Archaeometallurgical Investigations. Specimina electronica antiquitatis 1. Pécs 2013.

= K. SZENTMÁRTONI DARNAY: A sümeghi etruszk bronz edényekröl [On Etruscan bronze vessels from Sümegh]. ArchÉrt 9 (1889) 258-263.

= V. SZILÁGYI-Z. KIS-L. SZENTMIKLÓSI: Neutron imaging for archaeometry. Archaeometry Workshop (2016) 2016/XIII./3.

= T. R. Thomas-B.-G. Rosén-H. Zahouani-L. Blunt-M. El Mansori: Traceology, quantifying finishing machining and function: A tool and wear mark characterization study. Wear 271 (2011) 553-558.

= M. UCKelmann: Die Schilde der Bronzezeit in Nord-, West- und Zentraleuropa. PBF III/4. Stuttgart 2012.

\section{APPENDIX}

Table 1: XRF results of different parts of the artefact in mass percent unit. The uncertainty of the results was taken into account in the decimals. Note, that the sum of the results is not 100 in all case. Some other light elements, such as Al, Si, P were detected, but these are considered as elements of soil origin ${ }^{63}$ and not listed here in the table.

\begin{tabular}{|c|c|c|c|c|c|c|c|c|c|c|}
\hline Sheet & $\begin{array}{c}\text { Spectrum } \\
\text { code }\end{array}$ & Side & $\begin{array}{c}\text { Measurement } \\
\text { position }\end{array}$ & $\mathbf{F e}$ & $\mathbf{N i}$ & $\mathrm{Cu}$ & Sn & Sb & $\mathbf{P b}$ & $\mathbf{B i}$ \\
\hline \multicolumn{11}{|l|}{ Sheet A } \\
\hline & $\# 45 \mathrm{C}$ & rear & sheet & 0.48 & 0.10 & 95 & $<\mathrm{LOD}$ & $<\mathrm{LOD}$ & 0.11 & 0.07 \\
\hline & \#46C & rear & sheet & 0.28 & 0.10 & 94 & $<\mathrm{LOD}$ & $<\mathrm{LOD}$ & 0.08 & 0.07 \\
\hline & $\# 47 \mathrm{C}$ & rear & sheet & 0.47 & 0.09 & 95 & $<$ LOD & $<\mathrm{LOD}$ & 0.14 & 0.06 \\
\hline & \#48C & rear & sheet & 0.29 & 0.12 & 95 & $<$ LOD & $<\mathrm{LOD}$ & 0.10 & 0.07 \\
\hline & $\# 51 \mathrm{C}$ & rear & sheet & 0.29 & 0.10 & 95 & $<$ LOD & $<\mathrm{LOD}$ & 0.11 & 0.08 \\
\hline & $\# 52 \mathrm{C}$ & rear & sheet & 0.23 & 0.08 & 97 & $<\mathrm{LOD}$ & $<\mathrm{LOD}$ & 0.10 & 0.09 \\
\hline & $\# 53 \mathrm{C}$ & rear & sheet & 0.24 & 0.09 & 96 & 0.39 & $<\mathrm{LOD}$ & 0.11 & 0.08 \\
\hline & $\# 54 \mathrm{C}$ & rear & sheet & 0.31 & 0.08 & 95 & 0.45 & $<\mathrm{LOD}$ & 0.09 & 0.08 \\
\hline & $\# 55 \mathrm{C}$ & rear & sheet & 0.13 & 0.10 & 97 & 0.23 & $<$ LOD & 0.10 & 0.09 \\
\hline & \#49C & rear & sheet rim & 0.18 & 0.10 & 96 & $<\mathrm{LOD}$ & $<\mathrm{LOD}$ & 0.10 & 0.07 \\
\hline & $\# 50 \mathrm{C}$ & rear & sheet rim & 0.24 & 0.10 & 96 & $<\mathrm{LOD}$ & $<$ LOD & 0.09 & 0.08 \\
\hline & $\# 5 \mathrm{C}$ & front & sheet & 0.14 & 0.10 & 92 & $<\mathrm{LOD}$ & $<\mathrm{LOD}$ & 0.13 & 0.10 \\
\hline & $\# 23 \mathrm{C}$ & front & sheet & 0.34 & 0.11 & 88 & $<$ LOD & $<\mathrm{LOD}$ & 0.10 & 0.06 \\
\hline & $\# 61 \mathrm{C}$ & rear & hammering trace & 0.39 & 0.10 & 95 & $<\mathrm{LOD}$ & $<\mathrm{LOD}$ & 0.08 & 0.06 \\
\hline & $\# 2 \mathrm{C}$ & front & repoussé pattern & 0.18 & 0.11 & 92 & $<\mathrm{LOD}$ & $<\mathrm{LOD}$ & 0.12 & 0.06 \\
\hline & $\# 4 \mathrm{C}$ & front & repoussé pattern & 0.22 & 0.10 & 83 & $<\mathrm{LOD}$ & $<\mathrm{LOD}$ & 0.08 & 0.06 \\
\hline
\end{tabular}

${ }^{63}$ RoBbiola - BLENGino - FiaUd 1998 


\begin{tabular}{|c|c|c|c|c|c|c|c|c|c|c|}
\hline Sheet & $\begin{array}{l}\text { Spectrum } \\
\text { code }\end{array}$ & Side & $\begin{array}{c}\text { Measurement } \\
\text { position }\end{array}$ & $\mathrm{Fe}$ & $\mathrm{Ni}$ & $\mathrm{Cu}$ & Sn & $\mathrm{Sb}$ & $\mathbf{P b}$ & $\mathbf{B i}$ \\
\hline & $\# 34 \mathrm{C}$ & front & repoussé pattern & 0.06 & 0.12 & 98 & $<\mathrm{LOD}$ & $<\mathrm{LOD}$ & 0.13 & 0.09 \\
\hline & $\# 35 \mathrm{C}$ & front & repoussé pattern & 0.06 & 0.10 & 95 & $<\mathrm{LOD}$ & $<\mathrm{LOD}$ & 0.11 & 0.08 \\
\hline & $\# 37 \mathrm{C}$ & front & repoussé pattern & 0.12 & 0.12 & 89 & $<\mathrm{LOD}$ & $<\mathrm{LOD}$ & 0.12 & 0.08 \\
\hline & $\# 38 \mathrm{C}$ & front & repoussé pattern & 0.14 & 0.13 & 97 & $<\mathrm{LOD}$ & $<\mathrm{LOD}$ & 0.12 & 0.08 \\
\hline & \#36C & front & sheet & 0.12 & 0.10 & 96 & $<\mathrm{LOD}$ & $<\mathrm{LOD}$ & 0.12 & 0.08 \\
\hline & $\# 3 \mathrm{C}$ & front & shield rim & 0.15 & 0.14 & 92 & $<\mathrm{LOD}$ & $<\mathrm{LOD}$ & 0.27 & 0.21 \\
\hline & \#29C & front & shield rim & 0.15 & 0.09 & 97 & $<\mathrm{LOD}$ & $<\mathrm{LOD}$ & 0.16 & 0.05 \\
\hline & $\# 30 \mathrm{C}$ & front & shield rim & 0.29 & 0.11 & 96 & $<$ LOD & $<\mathrm{LOD}$ & 0.18 & 0.08 \\
\hline & $\# 31 \mathrm{C}$ & front & shield rim & 0.35 & 0.10 & 97 & $<\mathrm{LOD}$ & $<\mathrm{LOD}$ & 0.14 & 0.09 \\
\hline & $\# 32 \mathrm{C}$ & front & shield rim & 0.07 & 0.09 & 98 & $<\mathrm{LOD}$ & $<\mathrm{LOD}$ & 0.13 & 0.08 \\
\hline & $\# 33 \mathrm{C}$ & front & shield rim & 0.06 & 0.10 & 96 & $<\mathrm{LOD}$ & $<\mathrm{LOD}$ & 0.12 & 0.08 \\
\hline & $\# 92 \mathrm{C}$ & front & sheet & 0.23 & 0.09 & 90 & $<\mathrm{LOD}$ & $<\mathrm{LOD}$ & 0.10 & 0.07 \\
\hline & \#93C & front & sheet & 0.13 & 0.09 & 94 & $<\mathrm{LOD}$ & $<\mathrm{LOD}$ & 0.19 & 0.13 \\
\hline & \#94C & front & sheet & 0.15 & 0.10 & 90 & $<\mathrm{LOD}$ & $<\mathrm{LOD}$ & 0.17 & 0.12 \\
\hline & $\# 128 \mathrm{C}$ & front & sheet & 0.12 & 0.06 & 94 & $<\mathrm{LOD}$ & $<\mathrm{LOD}$ & 0.20 & 0.07 \\
\hline & $\# 129 \mathrm{C}$ & front & sheet & 0.21 & 0.11 & 94 & $<\mathrm{LOD}$ & $<\mathrm{LOD}$ & 0.17 & 0.13 \\
\hline & $\# 133 \mathrm{C}$ & front & sheet & 0.21 & 0.06 & 94 & $<\mathrm{LOD}$ & $<\mathrm{LOD}$ & 0.09 & 0.05 \\
\hline & $\# 134 \mathrm{C}$ & front & sheet & 0.13 & 0.09 & 95 & $<\mathrm{LOD}$ & $<\mathrm{LOD}$ & 0.14 & 0.10 \\
\hline & $\# 135 \mathrm{C}$ & front & sheet & 0.15 & 0.11 & 95 & $<\mathrm{LOD}$ & $<\mathrm{LOD}$ & 0.16 & 0.13 \\
\hline & $\# 136 \mathrm{C}$ & front & sheet & 0.08 & 0.09 & 97 & $<\mathrm{LOD}$ & $<\mathrm{LOD}$ & 0.13 & 0.08 \\
\hline \multicolumn{11}{|l|}{ Sheet B } \\
\hline & $\# 10 \mathrm{C}$ & front & sheet & 0.41 & $<\mathrm{LOD}$ & 82 & $<\mathrm{LOD}$ & $<\mathrm{LOD}$ & 0.13 & $<\mathrm{LOD}$ \\
\hline & $\# 11 \mathrm{C}$ & front & sheet & 0.06 & 0.03 & 95 & $<\mathrm{LOD}$ & $<\mathrm{LOD}$ & 0.13 & $<\mathrm{LOD}$ \\
\hline & $\# 12 \mathrm{C}$ & front & sheet & 0.07 & $<\mathrm{LOD}$ & 91 & $<\mathrm{LOD}$ & $<\mathrm{LOD}$ & 0.15 & $<\mathrm{LOD}$ \\
\hline & $\# 14 \mathrm{C}$ & front & sheet & 0.10 & 0.11 & 96 & $<\mathrm{LOD}$ & $<\mathrm{LOD}$ & 0.02 & $<$ LOD \\
\hline & $\# 102 \mathrm{C}$ & front & sheet & 0.16 & 0.08 & 95 & $<\mathrm{LOD}$ & $<\mathrm{LOD}$ & 0.03 & $<\mathrm{LOD}$ \\
\hline & $\# 104 \mathrm{C}$ & front & sheet & 0.15 & 0.11 & 95 & $<\mathrm{LOD}$ & $<\mathrm{LOD}$ & 0.03 & $<\mathrm{LOD}$ \\
\hline & $\# 106 \mathrm{C}$ & front & sheet & 0.15 & 0.09 & 96 & $<\mathrm{LOD}$ & $<\mathrm{LOD}$ & 0.03 & $<\mathrm{LOD}$ \\
\hline & $\# 107 \mathrm{C}$ & front & sheet & 0.48 & 0.07 & 85 & $<\mathrm{LOD}$ & $<\mathrm{LOD}$ & 0.02 & $<\mathrm{LOD}$ \\
\hline & $\# 108 \mathrm{C}$ & front & sheet & 0.12 & 0.10 & 96 & $<\mathrm{LOD}$ & $<\mathrm{LOD}$ & 0.03 & $<\mathrm{LOD}$ \\
\hline & $\# 109 \mathrm{C}$ & front & sheet & 0.12 & 0.08 & 96 & $<\mathrm{LOD}$ & $<\mathrm{LOD}$ & 0.02 & $<\mathrm{LOD}$ \\
\hline & $\# 110 \mathrm{C}$ & front & sheet & 0.18 & 0.09 & 95 & $<\mathrm{LOD}$ & $<\mathrm{LOD}$ & 0.03 & $<\mathrm{LOD}$ \\
\hline & $\# 122 \mathrm{C}$ & front & sheet & 0.13 & $<\mathrm{LOD}$ & 95 & $<\mathrm{LOD}$ & $<\mathrm{LOD}$ & 0.14 & $<\mathrm{LOD}$ \\
\hline & $\# 123 \mathrm{C}$ & front & sheet & 0.61 & 0.04 & 79 & $<\mathrm{LOD}$ & $<\mathrm{LOD}$ & 0.16 & $<\mathrm{LOD}$ \\
\hline & $\# 124 \mathrm{C}$ & front & sheet & 0.06 & $<\mathrm{LOD}$ & 92 & $<\mathrm{LOD}$ & $<\mathrm{LOD}$ & 0.18 & $<\mathrm{LOD}$ \\
\hline & $\# 125 \mathrm{C}$ & front & sheet & 0.09 & $<\mathrm{LOD}$ & 95 & $<\mathrm{LOD}$ & $<\mathrm{LOD}$ & 0.15 & $<\mathrm{LOD}$ \\
\hline & $\# 126 \mathrm{C}$ & front & sheet & 0.10 & $<\mathrm{LOD}$ & 95 & $<\mathrm{LOD}$ & $<\mathrm{LOD}$ & 0.15 & $<\mathrm{LOD}$ \\
\hline & $\# 127 \mathrm{C}$ & front & sheet & 0.06 & 0.02 & 92 & $<\mathrm{LOD}$ & $<\mathrm{LOD}$ & 0.16 & $<\mathrm{LOD}$ \\
\hline & \#130C & front & sheet & 0.18 & $<\mathrm{LOD}$ & 94 & $<\mathrm{LOD}$ & $<\mathrm{LOD}$ & 0.17 & $<\mathrm{LOD}$ \\
\hline
\end{tabular}




\begin{tabular}{|c|c|c|c|c|c|c|c|c|c|c|}
\hline Sheet & $\begin{array}{l}\text { Spectrum } \\
\text { code }\end{array}$ & Side & $\begin{array}{c}\text { Measurement } \\
\text { position }\end{array}$ & $\mathbf{F e}$ & $\mathrm{Ni}$ & $\mathrm{Cu}$ & Sn & $\mathbf{S b}$ & $\mathbf{P b}$ & $\mathbf{B i}$ \\
\hline & $\# 131 \mathrm{C}$ & front & sheet & 0.19 & $<\mathrm{LOD}$ & 95 & $<\mathrm{LOD}$ & $<$ LOD & 0.16 & $<\mathrm{LOD}$ \\
\hline & $\# 132 \mathrm{C}$ & front & sheet & 0.05 & $<\mathrm{LOD}$ & 96 & $<\mathrm{LOD}$ & $<$ LOD & 0.16 & $<\mathrm{LOD}$ \\
\hline & $\# 21 \mathrm{C}$ & front & sheet & 0.24 & $<\mathrm{LOD}$ & 86 & 0.75 & 0.08 & 0.51 & $<\mathrm{LOD}$ \\
\hline & $\# 111 \mathrm{C}$ & front & sheet & 0.13 & 0.02 & 91 & 0.32 & 0.11 & 0.57 & $<\mathrm{LOD}$ \\
\hline & $\# 112 \mathrm{C}$ & front & sheet & 0.19 & 0.02 & 93 & 0.53 & 0.12 & 0.63 & $<\mathrm{LOD}$ \\
\hline & \#113C & front & sheet & 0.14 & 0.02 & 95 & 0.37 & 0.10 & 0.55 & $<\mathrm{LOD}$ \\
\hline & \#114C & front & sheet & 0.19 & 0.03 & 90 & 0.26 & 0.10 & 0.43 & $<\mathrm{LOD}$ \\
\hline & $\# 115 \mathrm{C}$ & front & sheet & 0.13 & $<\mathrm{LOD}$ & 94 & 0.30 & 0.10 & 0.58 & $<\mathrm{LOD}$ \\
\hline & $\# 116 \mathrm{C}$ & front & sheet & 0.15 & 0.02 & 90 & 0.54 & 0.09 & 0.58 & $<\mathrm{LOD}$ \\
\hline & $\# 117 \mathrm{C}$ & front & sheet & 0.12 & 0.03 & 91 & 0.27 & 0.10 & 0.47 & $<\mathrm{LOD}$ \\
\hline & $\# 118 \mathrm{C}$ & front & sheet & 0.13 & 0.03 & 94 & 0.33 & 0.13 & 0.57 & $<\mathrm{LOD}$ \\
\hline & $\# 119 \mathrm{C}$ & front & sheet & 0.19 & $<\mathrm{LOD}$ & 99 & 0.45 & 0.12 & 0.56 & $<\mathrm{LOD}$ \\
\hline & $\# 120 \mathrm{C}$ & front & sheet & 0.17 & 0.02 & 90 & 0.24 & 0.10 & 0.51 & $<\mathrm{LOD}$ \\
\hline & $\# 121 \mathrm{C}$ & front & sheet & 0.09 & 0.03 & 93 & 0.28 & 0.09 & 0.54 & $<\mathrm{LOD}$ \\
\hline \multicolumn{11}{|l|}{ Sheet C } \\
\hline & $\# 17 \mathrm{C}$ & front & rivet & 0.17 & 0.04 & 87 & $<\mathrm{LOD}$ & $<$ LOD & 0.41 & $<\mathrm{LOD}$ \\
\hline & $\# 18 \mathrm{C}$ & front & rivet & 0.18 & $<\mathrm{LOD}$ & 85 & $<\mathrm{LOD}$ & $<\mathrm{LOD}$ & 0.03 & $<\mathrm{LOD}$ \\
\hline & \#19C & front & rivet & 0.16 & $<\mathrm{LOD}$ & 92 & $<$ LOD & $<$ LOD & 0.02 & $<\mathrm{LOD}$ \\
\hline & $\# 137 \mathrm{C}$ & front & rivet & 0.09 & 0.05 & 96 & $<\mathrm{LOD}$ & $<\mathrm{LOD}$ & 0.15 & $<\mathrm{LOD}$ \\
\hline & $\# 138 \mathrm{C}$ & front & rivet & 0.23 & $<\mathrm{LOD}$ & 90 & $<\mathrm{LOD}$ & $<\mathrm{LOD}$ & 0.07 & $<\mathrm{LOD}$ \\
\hline & $\# 139 \mathrm{C}$ & front & rivet & 0.09 & $<\mathrm{LOD}$ & 91 & $<$ LOD & $<$ LOD & 0.02 & $<\mathrm{LOD}$ \\
\hline & $\# 15 \mathrm{C}$ & front & sheet & 0.12 & 0.08 & 96 & $<\mathrm{LOD}$ & $<\mathrm{LOD}$ & 0.02 & $<\mathrm{LOD}$ \\
\hline & $\# 16 \mathrm{C}$ & front & sheet & 0.09 & $<$ LOD & 95 & $<\mathrm{LOD}$ & $<$ LOD & 0.03 & $<\mathrm{LOD}$ \\
\hline \multicolumn{11}{|l|}{ Sheet D } \\
\hline & $\# 8 \mathrm{C}$ & front & rivet & 0.12 & $<\mathrm{LOD}$ & 92 & $<\mathrm{LOD}$ & $<\mathrm{LOD}$ & 0.05 & $<\mathrm{LOD}$ \\
\hline & $\# 24 \mathrm{C}$ & front & rivet & 0.36 & $<\mathrm{LOD}$ & 93 & $<\mathrm{LOD}$ & $<$ LOD & 0.07 & $<\mathrm{LOD}$ \\
\hline & $\# 25 \mathrm{C}$ & front & rivet & 0.09 & $<\mathrm{LOD}$ & 92 & $<\mathrm{LOD}$ & $<$ LOD & 0.03 & $<\mathrm{LOD}$ \\
\hline & $\# 27 \mathrm{C}$ & front & rivet & 0.07 & $<$ LOD & 92 & $<\mathrm{LOD}$ & $<$ LOD & 0.03 & $<\mathrm{LOD}$ \\
\hline & $\# 56 \mathrm{C}$ & rear & rivet & 0.55 & $<\mathrm{LOD}$ & 94 & 1.1 & $<$ LOD & 0.03 & $<\mathrm{LOD}$ \\
\hline & $\# 57 \mathrm{C}$ & rear & rivet & 0.87 & $<\mathrm{LOD}$ & 95 & 0.35 & $<$ LOD & 0.10 & $<\mathrm{LOD}$ \\
\hline & \#59C & rear & rivet & 1.25 & $<\mathrm{LOD}$ & 93 & $<\mathrm{LOD}$ & $<$ LOD & 0.25 & $<\mathrm{LOD}$ \\
\hline & $\# 60 \mathrm{C}$ & rear & rivet & 0.41 & $<\mathrm{LOD}$ & 92 & $<\mathrm{LOD}$ & $<$ LOD & 0.03 & $<\mathrm{LOD}$ \\
\hline & \#6C & front & rivet & 0.08 & $<\mathrm{LOD}$ & 93 & 0.20 & $<\mathrm{LOD}$ & 0.23 & $<\mathrm{LOD}$ \\
\hline & $\# 141 \mathrm{C}$ & front & rivet & 0.16 & $<\mathrm{LOD}$ & 91 & $<\mathrm{LOD}$ & $<$ LOD & 0.03 & $<\mathrm{LOD}$ \\
\hline & $\# 142 \mathrm{C}$ & front & rivet & 0.16 & 0.02 & 92 & $<\mathrm{LOD}$ & $<\mathrm{LOD}$ & 0.06 & $<\mathrm{LOD}$ \\
\hline & $\# 7 \mathrm{C}$ & front & smaller rivet & 0.25 & 0.08 & 88 & $<\mathrm{LOD}$ & $<\mathrm{LOD}$ & 0.12 & 0.05 \\
\hline & $\# 9 \mathrm{C}$ & front & smaller rivet & 0.09 & 0.12 & 91 & $<\mathrm{LOD}$ & $<\mathrm{LOD}$ & 0.12 & 0.11 \\
\hline & $\# 26 \mathrm{C}$ & front & smaller rivet & 0.19 & 0.09 & 90 & $<\mathrm{LOD}$ & $<\mathrm{LOD}$ & 0.13 & 0.07 \\
\hline & $\# 28 \mathrm{C}$ & front & smaller rivet & 0.15 & 0.11 & 96 & $<\mathrm{LOD}$ & $<\mathrm{LOD}$ & 0.12 & 0.08 \\
\hline
\end{tabular}




\begin{tabular}{|c|c|c|c|c|c|c|c|c|c|c|}
\hline Sheet & $\begin{array}{c}\text { Spectrum } \\
\text { code }\end{array}$ & Side & $\begin{array}{c}\text { Measurement } \\
\text { position }\end{array}$ & $\mathrm{Fe}$ & $\mathbf{N i}$ & $\mathrm{Cu}$ & Sn & Sb & $\mathbf{P b}$ & $\mathbf{B i}$ \\
\hline & \#39C & rear & sheet & 1.27 & $<\mathrm{LOD}$ & 94 & $<\mathrm{LOD}$ & $<\mathrm{LOD}$ & $<\mathrm{LOD}$ & $<\mathrm{LOD}$ \\
\hline & $\# 40 \mathrm{C}$ & rear & sheet & 0.64 & $<\mathrm{LOD}$ & 95 & $<\mathrm{LOD}$ & $<\mathrm{LOD}$ & 0.02 & $<\mathrm{LOD}$ \\
\hline & $\# 41 \mathrm{C}$ & rear & sheet & 0.63 & $<\mathrm{LOD}$ & 96 & $<\mathrm{LOD}$ & $<\mathrm{LOD}$ & $<\mathrm{LOD}$ & $<\mathrm{LOD}$ \\
\hline & $\# 42 \mathrm{C}$ & rear & sheet & 1.74 & $<\mathrm{LOD}$ & 94 & $<\mathrm{LOD}$ & $<\mathrm{LOD}$ & 0.02 & $<\mathrm{LOD}$ \\
\hline & $\# 43 \mathrm{C}$ & rear & sheet & 1.48 & $<\mathrm{LOD}$ & 94 & $<\mathrm{LOD}$ & $<$ LOD & $<$ LOD & $<\mathrm{LOD}$ \\
\hline & \#44C & rear & sheet & 0.84 & $<\mathrm{LOD}$ & 95 & $<\mathrm{LOD}$ & $<\mathrm{LOD}$ & $<\mathrm{LOD}$ & $<\mathrm{LOD}$ \\
\hline & $\# 101 \mathrm{C}$ & rear & sheet & 0.78 & $<\mathrm{LOD}$ & 95 & $<\mathrm{LOD}$ & $<$ LOD & 0.02 & $<\mathrm{LOD}$ \\
\hline
\end{tabular}

